This is the final peer-reviewed accepted manuscript of

GIUNTOLI, FRANCESCO; Engi M.: Internal geometry of the central Sesia Zone (Aosta Valley, Italy): HP tectonic assembly of continental slices. SWISS JOURNAL OF GEOSCIENCES 109. 1661-8726

DOI: $10.1007 / \mathrm{s} 00015-016-0225-4$

The final published version is available online at:

http://dx.doi.org/10.1007/s00015-016-0225-4

Rights / License:

The terms and conditions for the reuse of this version of the manuscript are specified in the publishing policy. For all terms of use and more information see the publisher's website.

This item was downloaded from IRIS Università di Bologna (https://cris.unibo.it/)

When citing, please refer to the published version. 


\title{
Internal geometry of the central Sesia Zone (Aosta Valley, Italy): HP tectonic assembly of continental slices
}

\author{
Francesco Giuntoli $^{1}$ - Martin Engi ${ }^{1}$
}

\begin{abstract}
Detailed field mapping reveals that the Sesia Zone is subdivided into two complexes with the Barmet Shear Zone (BSZ) outlining the tectonic contact between them. This greenschist-facies contact reflects a metamor-phic gap between the Internal Complex (eclogite facies, eclogitic micaschists dominant) and the External Complex (epidote blueschist facies). The BSZ comprises a wedge shape area in which fragments and slices of orthogneiss and paragneiss are wrapped by siliceous dolomite marbles displaying a mylonitic foliation. Conspicuous cornieules and high pressure breccias occur along this contact. We propose that the eclogite facies Internal Complex is sub-divided into three basement units, called sheets, delimited by discontinuous metasedimentary trails of probable Mesozoic age. Thin monocyclic bands thus separate kilo-metre scale polycyclic sheets. The External Complex comprises three epidote blueschist facies sheets of com-parable size, which are separated by lenses retaining a pre-Alpine high temperature imprint. These weakly overprinted fragments (parts of the classically termed 2DK zone) are aligned along greenschist facies shear zones that separate the gneissic sheets. The BSZ, with a wedge rich in meta-sediments, chiefly siliceous dolomite marbles, is a key element in which fragmentation and reworking of materials
\end{abstract}

Editorial handling: E. Gnos.

Electronic supplementary material The online version of this article (doi:10.1007/s00015 01602254 ) contains supplementary material, which is available to authorized users.

Francesco Giuntoli

francesco.giuntoli@geo.unibe.ch

1 Institute of Geological Sciences, University of Bern, Baltzerstrasse 1+3, 3012 Bern, Switzerland from the internal and external complexes are evident. A carbonate breccia occurs in this shear zone, with clasts displaying a HP foliation randomly oriented in a ductile carbonate matrix. Siliceous dolomite marbles appear to have acted as lubricants to accommodate deformation related to the juxtaposition of the two basement complexes during exhumation. We propose a model of the Sesia Zone, with the BSZ as the thrust responsible for the juxtaposition of eclogite facies rocks of the Internal Complex on top of epidote blueschist facies rocks of the External Complex. The two complexes were already assembled when this shear zone became active. The entire stack was finally rotated (40 $60^{\circ}$ ) during the Vanzone Phase.

Keywords Sesia zone - HP metamorphism - Subduction . Microstructure · Alpine tectono-metamorphic · Italy

\section{Introduction}

Continental high-pressure terranes in a few orogens provide clues to understand how a previously passive margin behaves upon subduction. In such terranes it is difficult to infer the amount and style of extensional break-up that continental units had experienced prior to the onset of convergence (Mohn et al. 2011), as opposed to fragmentation during and after subduction. Enhanced mobility of tectonic fragments has been proposed to occur in a subduction (or accretion) channel (e.g. Cloos and Shreve 1988; Engi et al. 2001; Gerya and Stöckhert 2002; Warren et al. 2008), but few studies have documented how basement fragments actually form and behave in such a channel, and what role the distribution of weak lithotypes such as metasediments (e.g. carbonates) may play. 
The axial portion of the Western Alps exposes a structure that continental units acquired prior to, during and after subduction. These units represent a previously rifted distal continental margin (Beltrando et al. 2014), and some of them relate to extensional allochthons now exposed as slices resting on top of oceanic units. Alpine metamorphism (Oberhänsli et al. 2004) ranges from blueschist facies (widespread in external units) to eclogite facies (dominant in internal units), but in some basement units pre-Alpine remnants are common.

Any effort to unravel such a tectonic structure and to understand the assembly of continental units must link structural mapping of the polydeformed terrain with a sufficiently detailed analysis of its polymetamorphic record. Although this has long been recognized (e.g. Gosso 1977), there is a dearth of studies that combine the insight gained from detailed geological mapping and small scale petrostructural analysis (e.g. Zucali et al. 2002) with regional scale tectonic studies (e.g. Babist et al. 2006).

An effort to discern the internal geometry in the Sesia Zone was undertaken with the specific intent to clarify the regional make-up of this complex of high-pressure rocks and their evolution. This paper concentrates on a map-based analysis with a particular focus on the tectonic contacts between the complexes building up the Sesia Zone.

The specific goals of the study were (a) to map in detail the main complexes involved in the Sesia Zone and their contacts, in view of discrepancies in the literature; (b) to identify and map subunits within these complexes; (c) to analyze the units and contacts in terms of their metamorphic imprint, geometry, and structural features; (d) to propose a geometric model of the Sesia Zone based on the area studied.

\section{Geological setting}

The Alps are a collisional chain developed from the Cretaceous to the Neogene owing to the convergence of the European plate and the Adriatic plate; the latter is seen either a promontory of Africa or an independent microplate (e.g. Dewey et al. 1989; Rosenbaum et al. 2002; Dal Piaz et al. 2003; Handy et al. 2010).

In the Western Alps the oceanic units are represented by the Piemonte-Liguria Ocean; the continental crust of the Adriatic margin by the Ivrea Zone, the Canavese Zone, the Sesia Dent Blanche nappes and by several smaller tectonic fragments (e.g. the Verrès slice; Fig. 1).

The Piemonte-Liguria Ocean is subdivided into the Zermatt-Saas Unit and the Combin Unit. The Zermatt Unit represents a dismembered ophiolite sequence comprising pillow basalts, gabbros and serpentinites with associated meta-sediments (e.g. Bearth 1967; Cartwright and Barnicoat 2002). This unit experienced eclogite facies metamorphism, with a greenschist facies overprint localized

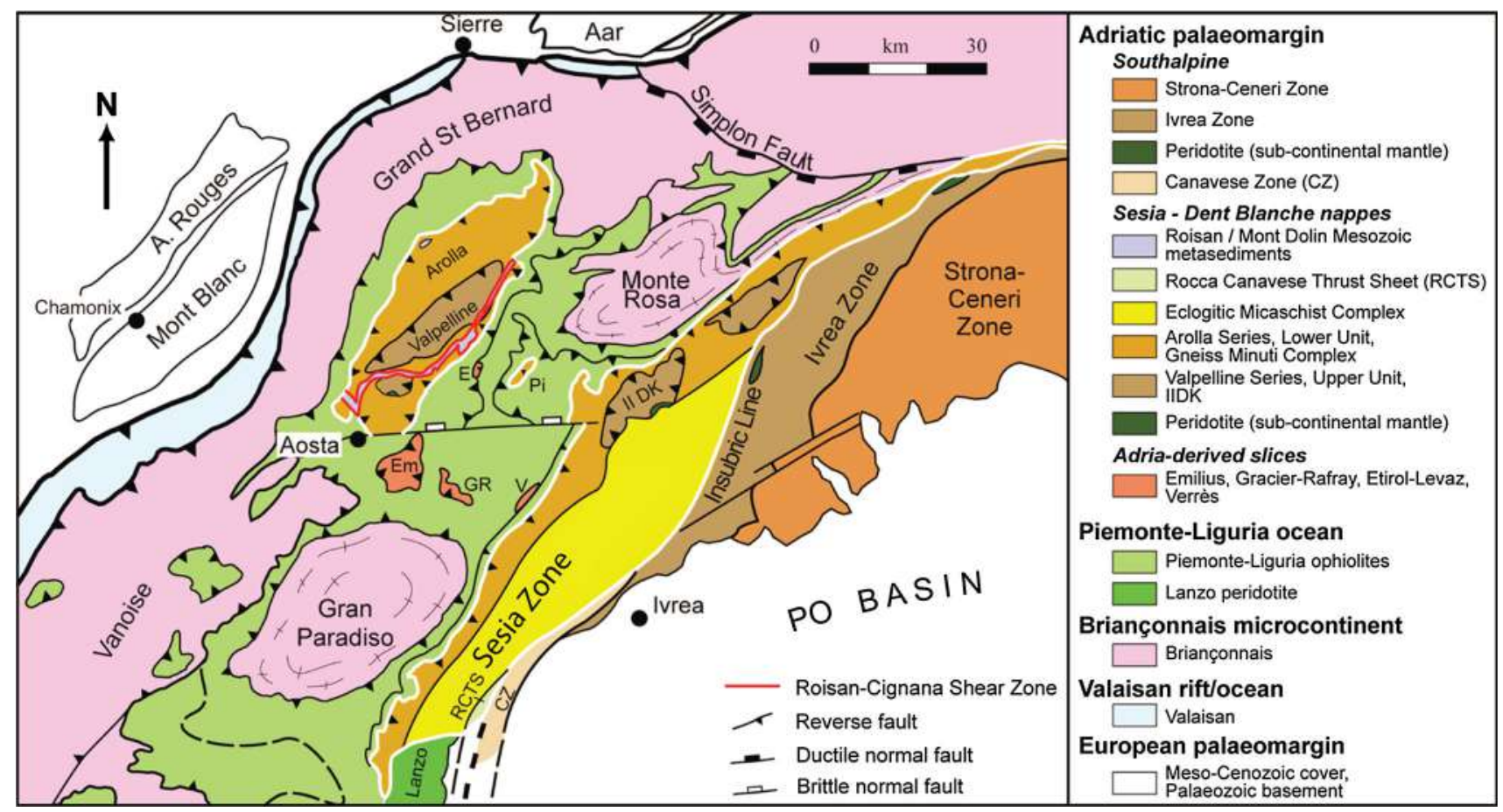

Fig. 1 Simplified tectonic map of the Western Alps (from Manzotti et al. 2014a, b) 
mostly close to tectonic contacts. The Combin Unit consists of calcschists, marbles and manganese quartzites with ophiolitic rocks in blueschist facies, but strongly re-equilibrated at greenschist grade (e.g. Ballèvre and Merle 1993; Barnicoat et al. 1995; Ring 1995).

The Sesia Dent Blanche nappes (e.g. Manzotti et al. 2014b) are the highest structural nappes of the Western Alps. They rest on top of the Combin Unit and comprise the Sesia Zone sensu stricto, the Dent Blanche klippe, and the Pillonet klippe (Fig. 1). The latter two are located to the west of the Sesia Zone s.s., and similarly they rest on top of the Combin Unit. By contrast, the Verrès, Etirol-Levaz, Emilius, Glacier Rafray, Acque Rosse and Tour Ponton slices are situated on top of the Zermatt-Saas Units but in the footwall of the Combin Unit (e.g. Argand 1911; Dal Piaz and Nervo 1971; Nervo and Polino 1976; Dal Piaz et al. 1979b, 1983; Bearth et al. 1980; Ballèvre et al. 1986; Pennacchioni 1990; Paganelli et al. 1995).

The Sesia Zone s.s. (simply termed Sesia Zone in the following), the target of this study, is an elongate body located in the Italian Western Alps (Fig. 1), with a NE SW trend, a maximum width of $25 \mathrm{~km}$ and a length of $\sim 100 \mathrm{~km}$ (e.g. Compagnoni et al. 1977). The Sesia Zone has long been recognised to be derived from the rifted NW margin of the Adriatic continent; it is bounded to the SE by the Insubric Line that separates it from the Southern Alps, and to the NW by the Gressoney Shear Zone (e.g. Wheeler and Butler 1993; Babist et al. 2006) that divides it from the blueschist facies Combin Unit of the Piemonte-Liguria Ocean.

The Sesia Dent Blanche nappes are believed to represent distal parts of a continental passive margin. Some of the slices may have represented, in Jurassic times, extensional allochthons in an ocean-continent transition zone (e.g. Dal Piaz 1999; Beltrando et al. 2014).

The Canavese Zone is bounded to the west by the southwestern portion of the Insubric line and to the east by a ductile fault zone that divide it from the Ivrea zone (Biino and Compagnoni 1989). It comprises ultramafic tectonic slivers, a granulite to amphibolite basement, similar to the Ivrea zone, followed by Triassic pre-rift carbonates, riftrelated clastic sediments, and a post-rift succession (Ferrando et al. 2004). The Alpine metamorphism is restricted to the prehnite-pumpellyite-actinolite facies (Biino and Compagnoni 1989; Borghi et al. 1996). The Canavese Zone represents the distal continental margin of Adria in a setting of ocean-continent transition (Ferrando et al. 2004).

The Ivrea Zone belongs to the Southern Alps and is separated from the Sesia Zone by the Insubric line. An extensive cross section through the lower pre-Alpine crust is exposed in the Ivrea Zone, consisting of amphibolite to granulite facies meta-sediments (Kinzigite formation), mantle peridotites and mafic intrusives (Mafic complex) with a generally weak Alpine overprint at sub-greenschist facies (e.g. Bertolani 1954, 1959; Rivalenti et al. 1975; Zingg 1983; Quick et al. 2003).

\section{Subdivision of the Sesia Zone s.s}

\subsection{Historical subdivisions and characterisation of contacts}

A first subdivision of the Sesia Zone was proposed by Italian geologists at the end of the 19th century. They identified three units and used the most common lithotype in each of them as a name for these units: Eclogitic Micaschists (here after referred to as EM; Stella 1894), Gneiss Minuti (here after referred to as GM; Gastaldi 1871, 1874) and the Seconda Zona Diorito-Kinzigitica (here after referred to as 2DK; e.g. Artini and Melzi 1900). These terms have been retained in many subsequent studies without major change (e.g. Dal Piaz et al. 1971, 1972; Compagnoni 1977; Compagnoni et al. 1977; Gosso et al. 1979; Lardeaux et al. 1982), but different views have been proposed, in particular to delineate and interpret the internal geometry of the Sesia Zone. In essence, the evo-lution of thought can be grouped into seven end-members:

1. The Sesia Zone shows a synformal structure, with the 2DK as the upper element lying in tectonic contact with a lower element comprising the EM and GM (Fig. 2a). The juxtaposition of these two units took place after a high-pressure stage (Carraro et al. 1970; Dal Piaz et al. 1971, 1972; Compagnoni et al. 1977). According to Lardeaux (1981) and Lardeaux et al. (1982) the contact between the 2DK and EM is marked by eclogite facies mylonites.

2. Three tectonic units were juxtaposed to produce the Sesia Zone (Gosso 1977; Passchier et al. 1981; Williams and Compagnoni 1983; and Vuichard 1986). In the model proposed by Williams and Compagnoni (1983) the main contact between the EM and GM is a thrust (Fig. 2b) probably established at greenschist facies conditions, locally folded and marked by Mesozoic dolomite carbonates (Vuichard 1989).

3. Ridley (1989) proposed that the assembly of the Sesia Zone is the result of two phases of sinistral strike-slip motion reworking the previously flat lying contact between EM and 2DK. The first strike-slip motion is transtensive, occurs at blueschist facies condition and is responsible for the juxtaposition of the EM with the 2DK. The second phase is transpressive and occurs at greenschist facies, resulting in juxtaposing the EM + 2DK against the GM (Fig. 2c). 
Fig. 2 Schematic models illustrating possible scenarios for the internal subdivisions of the Sesia Zone. All references in the text
NW

(a) a post-nappe synform (Dal Piaz et al. 1972; Compagnoni et al. 1977)

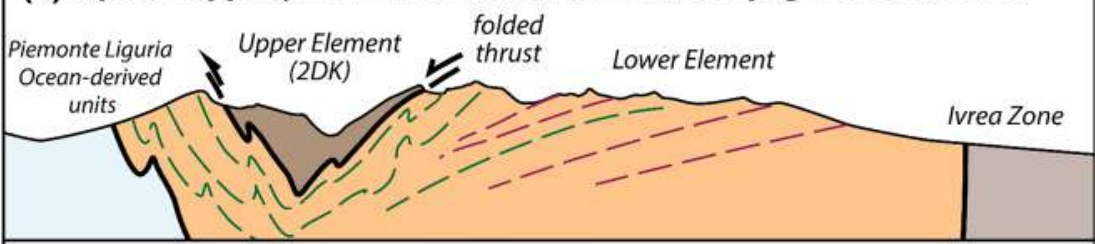

(b) ductile (thrust) SZ (Williams \& Compagnoni 1983; Vuichard 1989)

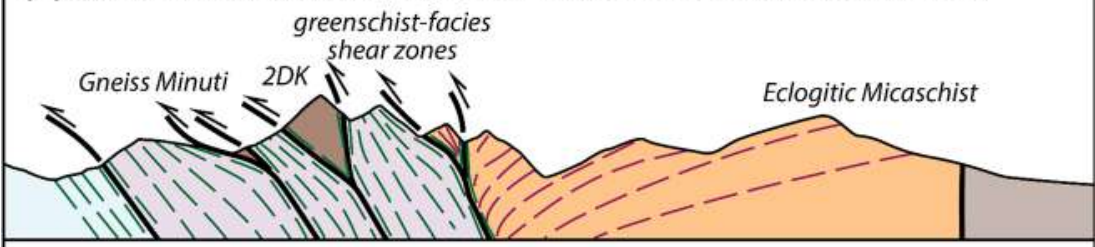

(c) ductile trantensive then transpressive SZ (Ridley 1989)

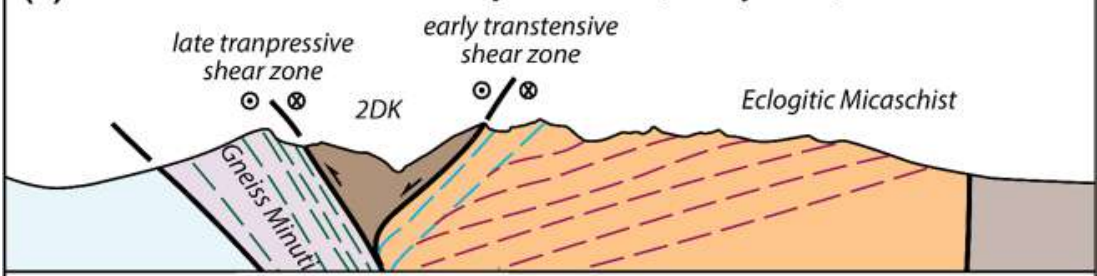

(d) anastomosing SZ cutting across the HP fabrics (Spalla et al. 1991)

increasing strain at greenschist-facies conditions

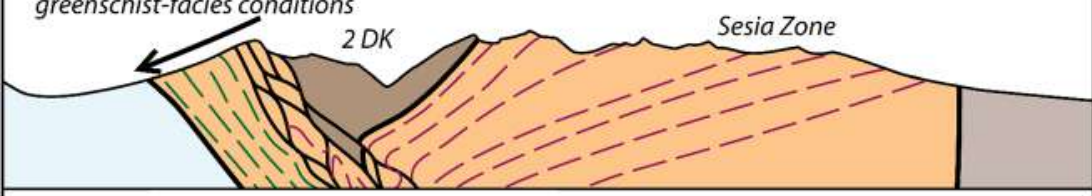

(e) folded nappes bounded by Mesozoic covers (Venturini et al. 1994)

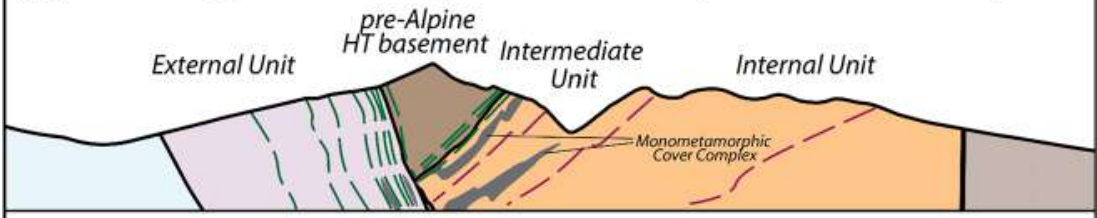

(f) an early ductile normal fault cut across by a reverse fault (Avigad 1996)

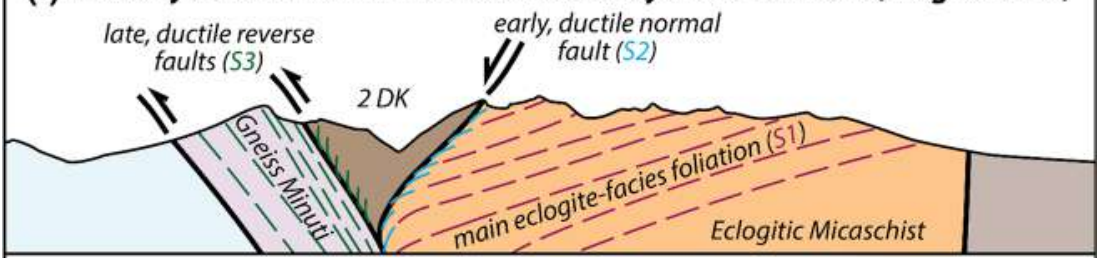

(g) two nappes separated by monocyclic meta-sediments. Fabric domains cut these nappes (Babist et al. 2006)

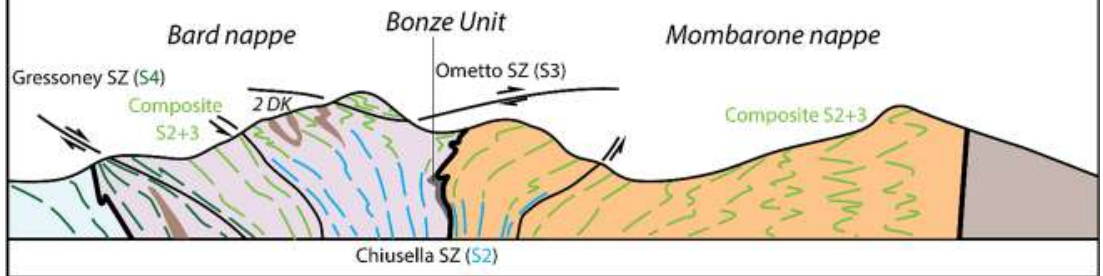


4. In a model (Fig. 2d) proposed by Spalla et al. (1991) the differences between the EM and GM are secondary, as both units are thought to have experienced eclogite facies conditions. The EM and GM essentially differ by the amount of strain they experienced at greenschist facies, i.e. the external (GM) part of the Sesia Zone is affected by anastomosing shear zones, causing strong retrogression.

5. Venturini et al. (1994) proposed an internal subdivision of the EM into subunits identified on the basis of interleaved meta-sediments presumed to be monometamorphic (Fig. 2e).

6. Avigad (1996) found that the EM shows a main eclogite facies foliation (S1) and that the contact with the $2 \mathrm{DK}$ is a ductile normal fault (S2) that operated at blueschist facies, postdating the eclogite facies foliation. A late greenschist facies thrust (S3) emplaces these two on top of the GM (Fig. 2f).

7. Babist et al. (2006) proposed a new subdivision of the Sesia Zone into two nappes, i.e. the Mombarone Nappe (internal) and the Bard Nappe (external), separated by meta-sediments again viewed as monometamorphic (Bonze unit). Babist et al. (2006) discussed that the juxtaposition between Mombarone and 2DK was overprinted by the Chiusella Shear Zone at retrograde conditions, from eclogite to blueschist and finally greenschist facies; subhorizontal to moderately plunging stretching lineations suggest sinistral strike-slip or oblique slip motion, similar to Ridley (1989). The contact between the Mombarone and Bard nappe initiated with oblique-slip at retrograde eclogite to greenschist facies conditions, followed by top to E-SE extensional shearing in the greenschist facies (Ometto Shear Zone, Babist et al. 2006). The contact between the Bard nappe and large parts of the Liguria-Piemonte domain is marked by the Gressoney Shear Zone with a top to SE sense of shear noted also by Wheeler and Butler (1993). This shear zone shows a retrograde greenschist facies schistosity oriented parallel to the base of the Bard nappe (Fig. 2g).

Despite the many advances summarized above, the evolution of thought has not lead to a universally accepted view of the tectonometamorphic structure and evolution of the Sesia Zone. Furthermore, detailed petrochronological work (Rubatto et al. 2011; Regis et al. 2014) revealed substantial differences in the evolution within the internal unit of the Sesia Zone (i.e. EM or Mombarone). The discrepant pressure temperature time (PTt) paths docu-mented in these studies imply that this internal complex must comprise tectonic subunits so far not recognised in the field. The complex evolution of the basement rocks in each of these units requires particular attention to their polyphase deformational and metamorphic evolution (e.g. Zucali et al. 2002; Gosso et al. 2010).

\subsection{Metamorphism in units of the central Sesia Zone}

Pre-Alpine HT relics in the EM suggest granulite (0.6 $0.9 \mathrm{GPa}, \sim 850{ }^{\circ} \mathrm{C}$ ) and retrograde amphibolite conditions (0.5 0.3 GPa, $570670{ }^{\circ} \mathrm{C}$; Lardeaux and Spalla 1991; Rebay and Spalla 2001). A similar pre-Alpine metamorphic history was described for the 2DK by Dal Piaz et al. (1971) and Vuichard (1987).

During Alpine metamorphism the EM experienced 2.0 GPa and $500600{ }^{\circ} \mathrm{C}$ as maximum pressure $(P)$ and temperature $(T)$ (Compagnoni 1977; Konrad-Schmolke et al. 2006). Rubatto et al. (2011) and Regis et al. (2014) proposed a tectonometamorphic subdivision of the EM, as substantially different PTt-evolutions were found in two subunits (termed Druer and Fondo slices). The Druer slice, the most internal unit, experienced eclogite facies at $\sim 85 \mathrm{Ma}, 2.0 \mathrm{GPa}$ and $560{ }^{\circ} \mathrm{C}$, followed by decompression at $\sim 74 \mathrm{Ma}, 1.6 \mathrm{GPa}$ and $600{ }^{\circ} \mathrm{C}$. By contrast, the Fondo slice, in a more external position, shows an eclogite facies peak at $\sim 75 \mathrm{Ma}, 1.7 \mathrm{GPa}$ and $530{ }^{\circ} \mathrm{C}$, then a decompression stage at $\sim 68 \mathrm{Ma}$, and a second HP stage between 65 and $60 \mathrm{Ma}$ for $P$ between 1.4 and $2.0 \mathrm{GPa}$ and $\sim 550{ }^{\circ} \mathrm{C}$. The boundaries between these slices have not been mapped so far.

No modern $P T$ data are available for the Alpine metamorphism of the GM and the 2DK for the study area. Gosso (1977) found that the GM experienced lower pressures than the EM, and Williams and Compagnoni (1983) stated that there is a jump in the metamorphic conditions from Jd + Qz (mineral abbreviations according to Whitney and Evans (2010) with Wm for white mica) in the EM to Pl in the GM. According to Lardeaux (1981) the juxtaposition between the $2 \mathrm{DK}$ and the EM occurred at $\sim 14 \mathrm{kbar}$ and $500{ }^{\circ} \mathrm{C}$.

\subsection{Criteria used to subdivide units}

In view of the structural complexity and variable metamorphic imprint, a set of field criteria was used, aiming to delimit the first order tectonic units (Table 1).

The first criterion used was to identify and map Mesozoic meta-sediments in the study area. These are represented by trails of dolomite marbles (with rare basic layers) and cornieules that were considered to be mono-cyclic (Mesozoic in age) because of the affinity with Triassic sediments found in the Southern Alps (e.g. Berra and Carminati 2010 and references therein), in the Roisan Zone (Manzotti et al. 2014a, b; Ciarapica et al. 2016), and in the Campolungo area of the Central Alps (Bianconi 
Table 1 Field criteria used to delimit the first order tectonic units

\begin{tabular}{lllll}
\hline Complex & Unit & $\begin{array}{l}\text { Presumed monocyclic } \\
\text { meta sediments }\end{array}$ & $\begin{array}{l}\text { Mappable high strain } \\
\text { zones }\end{array}$ & $\begin{array}{l}\text { Differences in the } \\
\text { metamorphic } \\
\text { and } \\
\text { structural imprint }\end{array}$ \\
\hline Internal & Croix Courma & $\mathrm{X}$ & $\mathrm{X}$ & $\mathrm{O}$ \\
& Loses Blanches & $\mathrm{X}$ & $\mathrm{O}$ & $\mathrm{O}$ \\
& Prial & $\mathrm{X}$ & $\mathrm{O}$ & $\mathrm{O}$ \\
Barmet SZ & Crabun & $\mathrm{O}$ & $\mathrm{X}$ & $\mathrm{O}$ \\
External & Aquila Lago & $\mathrm{O}$ & $\mathrm{X}$ & $\mathrm{X}$ \\
& Dondeuil & $\mathrm{O}$ & $\mathrm{X}$ & $\mathrm{X}(\mathrm{pre}$ Alpine) \\
& Nery Torché & $\mathrm{O}$ & $\mathrm{X}$ & $\mathrm{O}$ \\
& Chasten & $\mathrm{O}$ & $\mathrm{X}$ & $\mathrm{X}$ (pre Alpine) \\
\hline
\end{tabular}

$X$ present, $O$ not observed

1971). Other types of meta-sediments found in the area mapped are considered to be monocyclic because of the succession of several lithologies (i.e. marble, calcschist, impure quartzite and mafic layers) and their affinity with Mesozoic sequences described in the Western Alps (e.g. Elter 1971; Dal Piaz 1974), as proposed by Compagnoni (1977). In the meta-sediments considered monocyclic, we note that pre-Alpine high-temperature relics are lacking, whereas these are conspicuous in polycyclic meta-sediments (e.g. Castelli 1991). As a check, Raman spectroscopy on carbonaceous material was used (albeit only for one meta-sediment; Online Resource 4) to verify that the sample experienced a maximum temperature corresponding to Alpine conditions (i.e. not exceeding $\sim 600^{\circ} \mathrm{C}$ ).

A second criterion was to recognize the polycyclic character of rocks, either by the presence of relics, such as a metamorphic fabric cut by aplitic or pegmatitic dykes (indicative of pre-Alpine age because in the Sesia Zone no such intrusives are known from the Alpine cycle), or visible high-temperature mineral relics (amphibolite or granulite facies), or by characteristic polycyclic minerals (e.g. garnet with a high-temperature core).

The third criterion was to localize and describe tectonic boundaries between different units based on the differences in the metamorphic imprint as well as the presence of high strain zones (shear zones).

For tectonic subdivisions proposed on the basis of the above criteria, the following terminology is used: A complex describes a first-order tectonometamorphic body that comprises different units. Where such a unit is lenticular or involves several lens-shaped bodies, it is termed a slice, whereas laterally more uniform and extensive bodies are termed sheets. All of these units are at least several hun-dred meters to a few kilometres in size.

\subsection{Delimitation of tectonic units in the area mapped}

The study area is located in the Aosta Valley, between the villages of Pont-Saint-Martin, Verrès, Gaby and Brusson (Fig. 3; Online Resource 1). Field criteria (Table 1) applied in mapping (at 1:10,000 and, where needed, at 1:3000 scale) and subsequent laboratory analysis (some 250 samples) were integrated to produce the map shown in Fig. 4 (Online Resource 1).

We propose a subdivision into an Internal Complex and an External Complex. The Internal Complex extends eastward of a NNE-SSW line that connects Bard with Pont de Trenta and corresponds to the EM of Williams and Compagnoni (1983) and Passchier et al. (1981). The External Complex lies westward of this line and encompasses the GM and the IIDK of Williams and Compagnoni (1983) and Passchier et al. (1981). The Barmet Shear Zone is a kilometre scale high strain zone that separates these two complexes.

\subsubsection{Internal Complex}

The Internal Complex covers the area east of Bard, Col de la Cou, Cime P. Blanches, Mont de Prial, Mont Nery, Pont de Trenta (Figs. 3, 4; Online Resource 1). Characteristic of this complex is an alternance of bands and elongate bodies of micaschist, eclogite, ortho- and paragneiss, and leucogneiss (Fig. 5a d). Relative abundances vary widely, but generally the micaschists make up more than $50 \%$. Bands range in thickness from less than a millimetre to tens of meters; individual bodies extend up to several hundred metres in length. The contacts between these lithotypes are mainly transposed parallel to the eclogitic foliation, transitions between the lithotypes can be sharp or gradational 


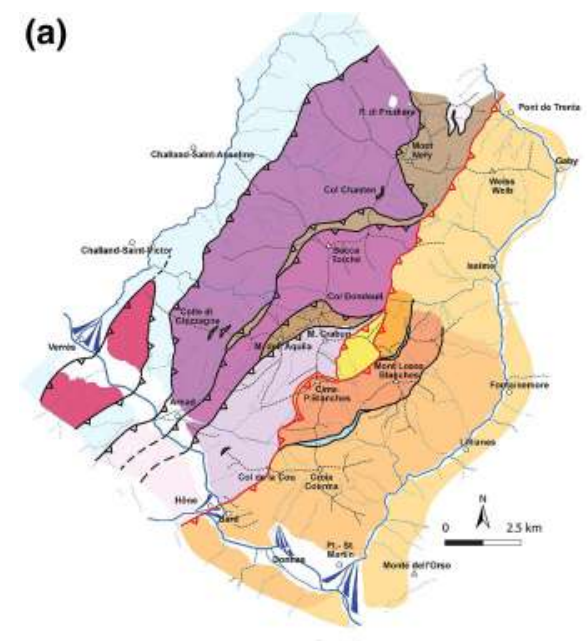

TECTONIC SKETCH

ADRIA-DERIVED SLICES

verrès slice

SESIA ZONE

EXTERNAL COMPLEX

Chasten sheet

20K lithotypes-Nen-Torché slice

Dondents seet

Gothen sheet Mquia-Lago slico

Und fferentised d

BARMET SHEAR ZONE

INTERNAL COMPLEX

Preal sthet

Lases Blanches sheet

Undifferentianed intornal Complo

PIEMONTE LIGURIA

OCEAN-DERIVED UNITS

Undifferentiated

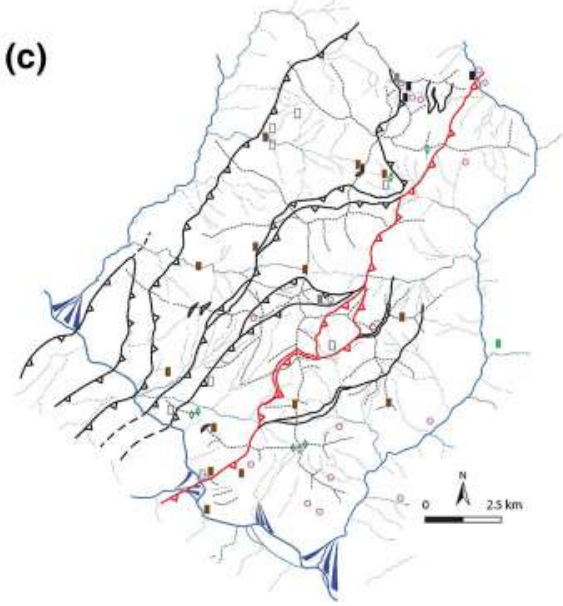

PRE-ALPINE RELICS

METAMORPHIC HT RELICS

- Homblende

1. Plagioclase

1. Blotite

MAGMATIC RELICS

1. K-feldspat
Fig. 3 a Tectonic sketch of the area studied, showing the Internal and External Complexes and internal sub units of the Sesia Zone. Tectonic boundaries are shown as continuous lines where outcrop ping; dashed lines are interpretive boundaries. The red colour indicates the tectonic contact between the Internal and External Complexes. b Map of the main metamorphic imprint of the studied area: in the Internal Complex only areas close to the contact with the

due to variable proportions of mafic and felsic minerals. A detailed description of the lithotypes is part of the supplementary material (Online Resource 2).

The Internal Complex shows several types of carbonate meta-sediments:

- Type 1: a kilometre-scale lens of impure marble near Fontainemore containing pre-Alpine high-temperature relics (Castelli 1991; Online Resource 1),

- Type 2: isolated pure or siliceous marble lenses or bands with a lateral continuity of some decametres to hectometres (e.g. close to Croix Courma; Fig. 4),

- Type 3: trails of carbonate-bearing meta-sediments aligned as the main eclogitic foliation over a distance of $1 \mathrm{~km}$, E of Mt Prial, to $3 \mathrm{~km}$ at Col Fenêtre, $<1050 \mathrm{~m}$ in thickness (Fig. 4).
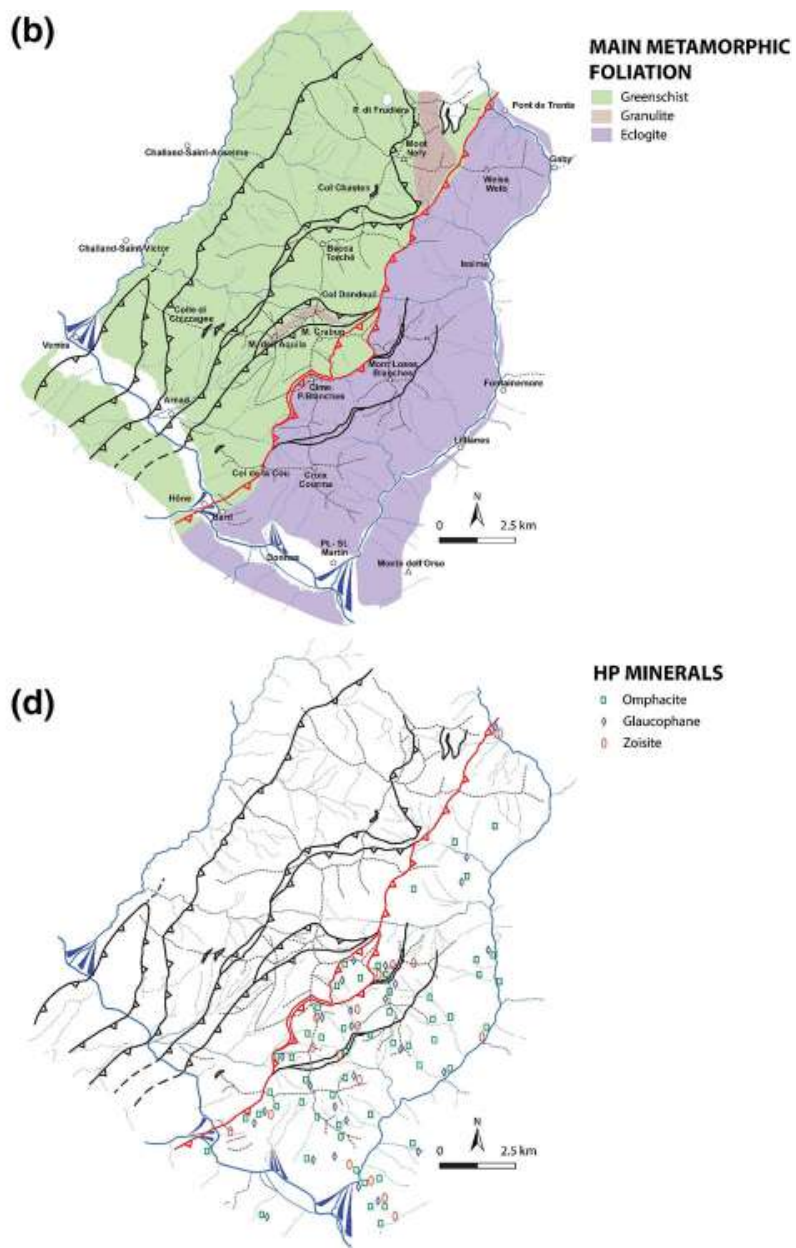

External Complex are affected by a greenschist facies overprint. c Map of the pre Alpine metamorphism and magmatism: pre Alpine metamorphic relics are found in the Internal Complex, whereas in the External Complex they were found only in the Nery Torché and Aquila Lago slices and in few amphibolites in the Crabun Sheet. d Map showing the distribution of HP minerals. They were found exclusively in the Internal Complex and in the Barmet SZ

Type 2 meta-sediments are considered to be of uncertain age, as they lack distinctive features (such as pre-Alpine high-temperature relics) and because they are not found in close association with distinctive meta-sediments.

Type 3 comprises calcschists (Fig. 5b), siliceous marbles, and impure quartzites with sparse eclogites at Col Fenêtre, as well as siliceous dolomite marbles and minor cornieules S and E of Mont Prial. Raman spectroscopy was performed on carbonaceous material from a calcschist located E of Mont Fenêtre (Fig. 4). The maximum temperatures recorded range between 520 and $615{ }^{\circ} \mathrm{C}$ (see Online Resource 4). These data are in line with Alpine metamorphic temperatures estimated by Regis et al. (2014) in this area and corroborate the hypothesis that these sediments are monocyclic, as temperatures of Permian 


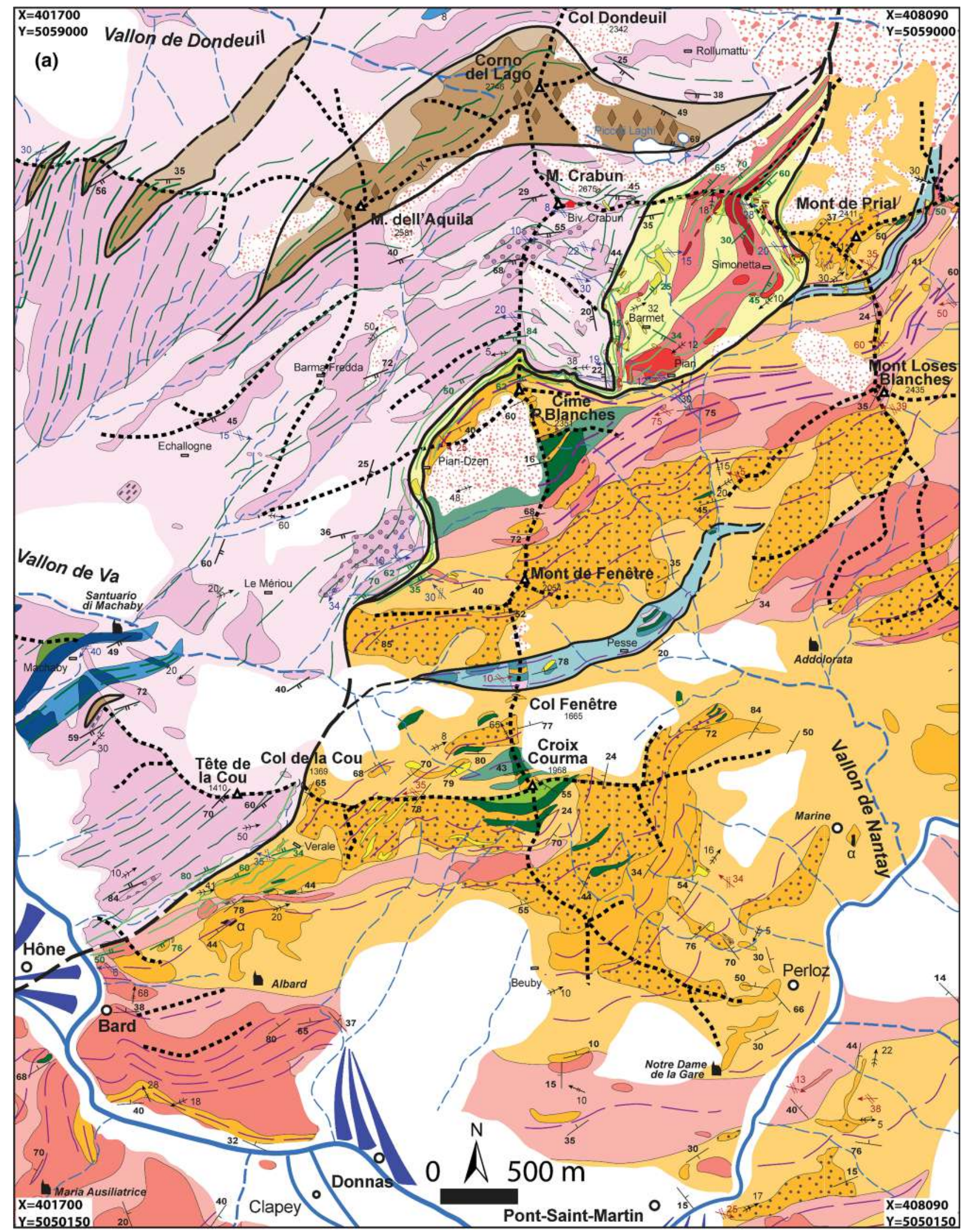


4Fig. 4 Petrographic and structural map of the study area (full size document in the Online Resource 1) with legend. UTM ED 1950, $32 \mathrm{~N}$ coordinates given for the vertices of the map

metamorphism were considerably higher. Finally, it is noteworthy that a very similar sequence of meta-sediments occurs near Cima di Bonze (Scalaro unit, Venturini et al. 1994), where detailed work (Regis et al. 2015) also concluded that this unit is monocyclic. Venturini (1995) was the first to have made this proposition based on a series of profiles documented south of the area studied here.

The lithological similarity of the observed meta-sediments to Mesozoic covers and the absence of HT preAlpine relics lead us to interpret these two sequences (i.e. meta-sediments of Types 3) as monocyclic. Their extent is indicated in light blue in the map of Fig. 4 and Online Resource 1.
The Internal Complex was subdivided into three eclogitic sheets, each $0.53 \mathrm{~km}$ thick, the contacts of which are marked by these presumed monometamorphic meta-sediments; these units are termed Croix Courma sheet, Loses Blanches sheet, and Prial sheet, from internal to external.

A greenschist facies overprint is pervasive in the Internal Complex close to its tectonic contact with the External Complex. The overprint extends $50300 \mathrm{~m}$ from that contact, and it is typically associated with a mylonitic foliation. In the rest of the Internal Complex this greenschist overprint is absent to weak and mostly static.

\subsubsection{External Complex}

The External Complex is located west of the Internal Complex (Figs. 3, 4; Online Resource 1).

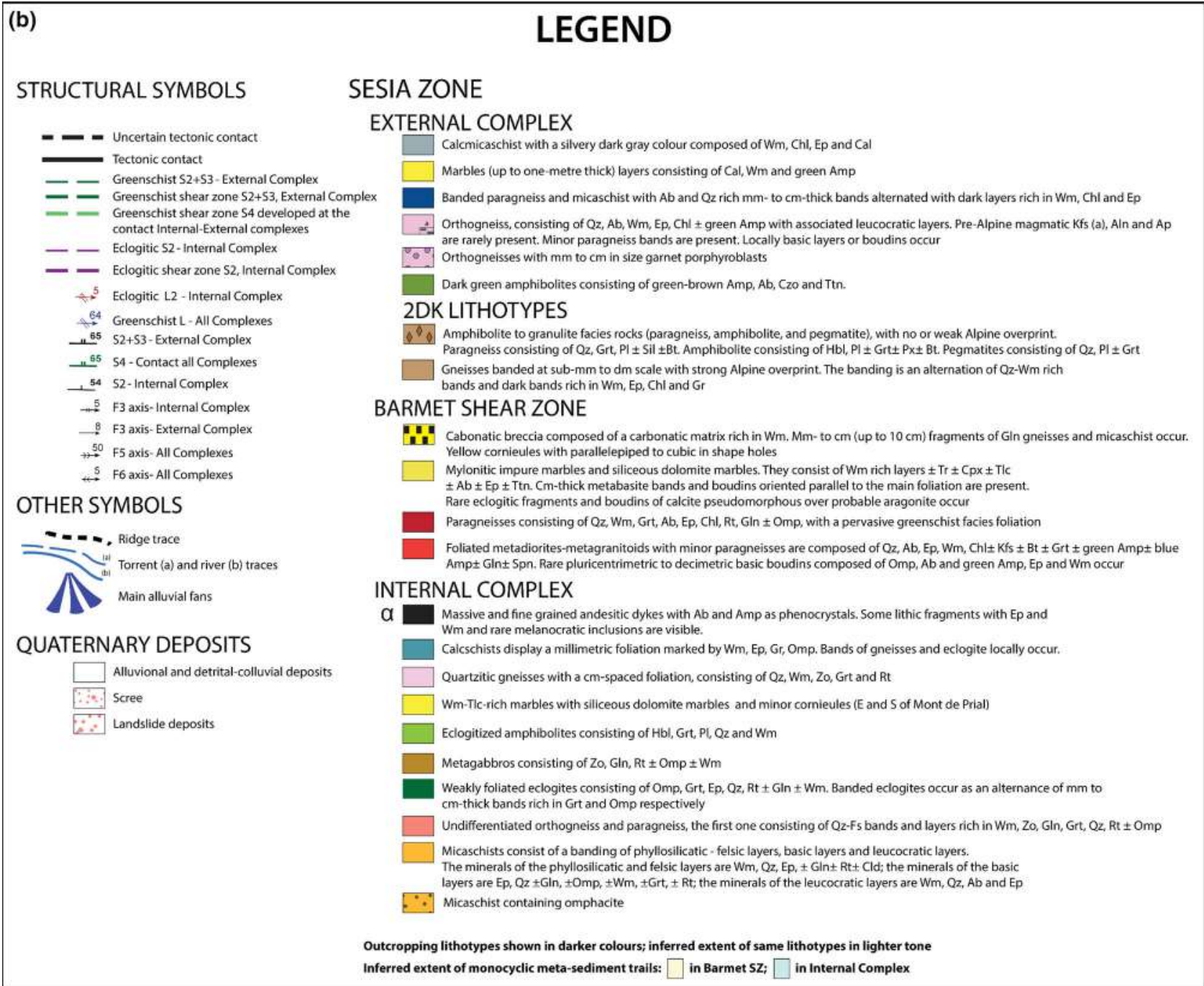

Fig. 4 continued 
INTERNAL COMPLEX
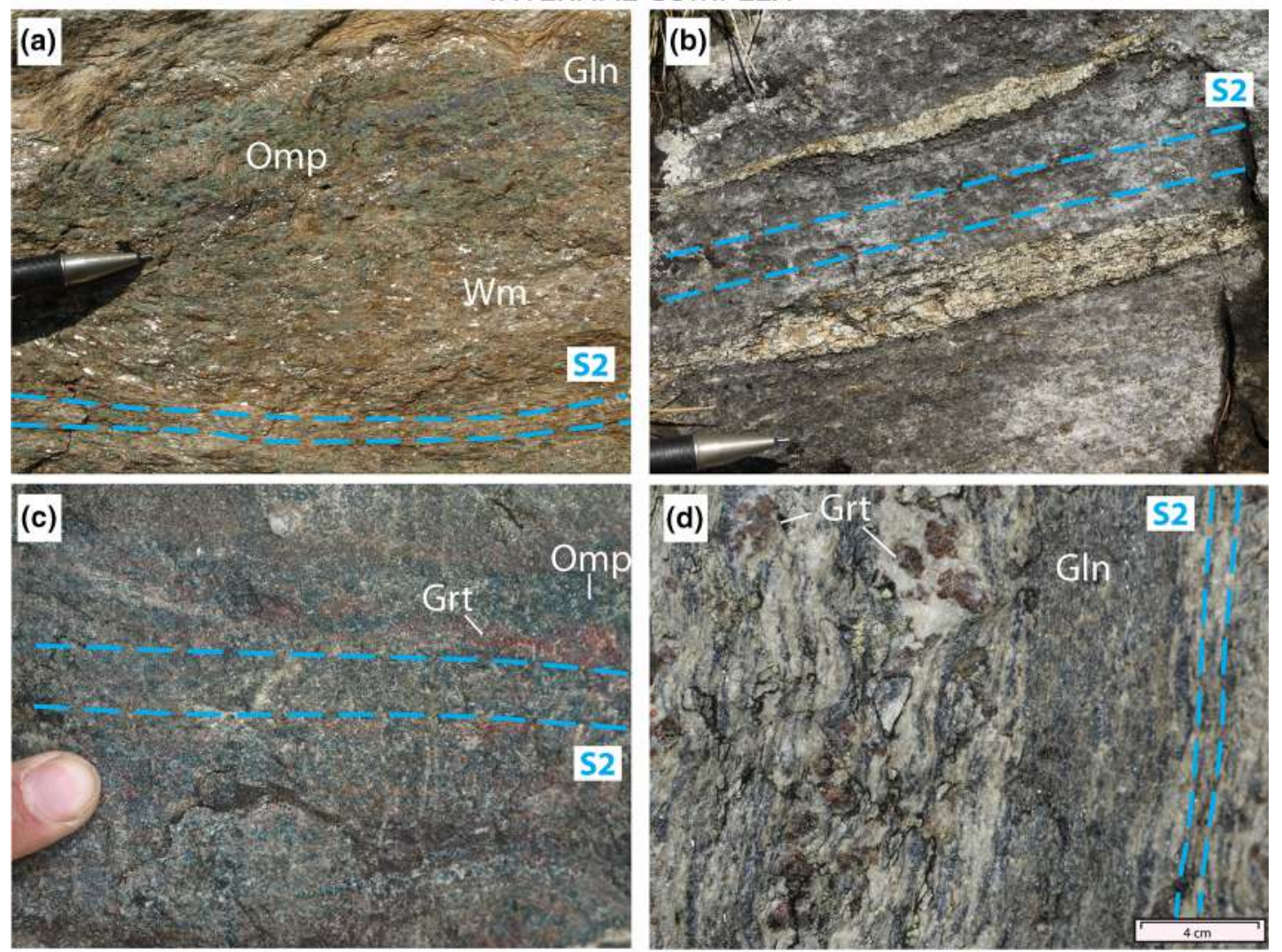

EXTERNAL COMPLEX
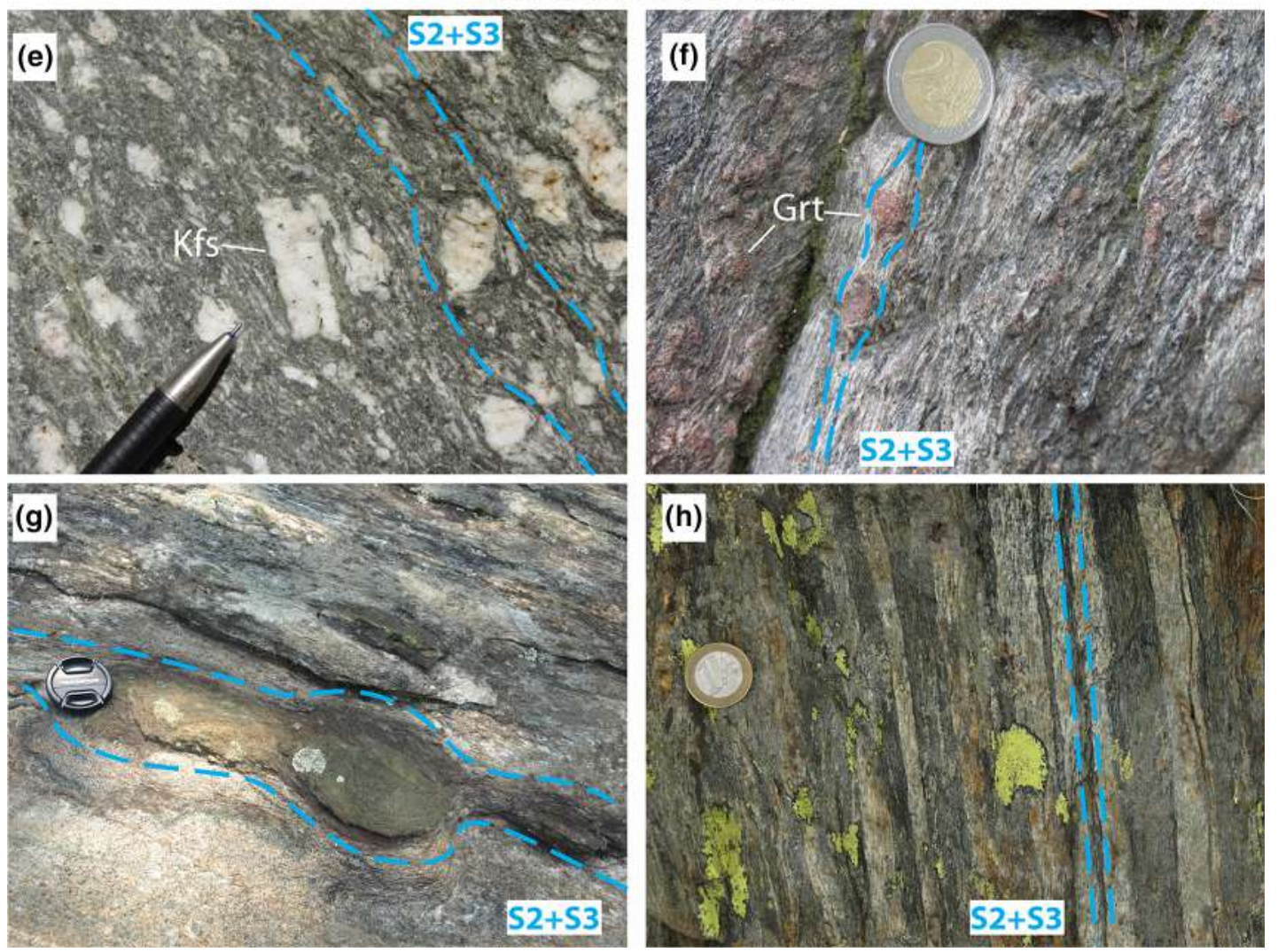
4 Fig. 5 Lithotypes of the Internal Complex: a Micaschist with a rusty weathering colour and displaying an eclogitic foliation S2 marked by Omp, Gln and Wm (Croix Courma sheet). b Calcschist with $\mathrm{cm}$ size bands of felsic composition, marking the S2 foliation (Col Fenêtre monometamorphic meta sediments). c Eclogite with garnet rich bands and omphacite rich ones (Internal Complex). d Gneiss with Gln rich bands and fragmented Grt wrapped by the mylonitic eclogitic foliation S2 (Loses Blanches sheet). Lithotypes of the External Complex. e Orthogneiss with $\mathrm{cm}$ size magmatic Kfs wrapped by the composite $\mathrm{S} 2+\mathrm{S} 3$ foliation (Crabun sheet). f Orthogneiss with $\mathrm{mm}$ size Grt wrapped by the composite S2 $+\mathrm{S} 3$ foliation (Crabun sheet). $\mathrm{g}$ Basic boudinated layer inside orthogneiss (Dondeuil sheet). $\mathbf{h} 2 \mathrm{DK}$ derived banded gneiss with $\mathrm{Qz}$ and $\mathrm{Ab}$ bands (light) and Chl, Ep $\pm \mathrm{Gr}$ bands (dark) (Aquila Lago slice). Field photos coordinates are included in Online Resource 3

The most evident and sharp contacts in the External Complex delimit the 2DK lithotypes, which stand out in the field due to rusty weathering colours contrasting against light grey orthogneisses and minor paragneisses (Fig. 5e h). The 2DK lithotypes display either a perfectly preserved preAlpine high-temperature assemblages at amphibolite to granulite facies or a strong Alpine overprint with a development of a pervasive to mylonitic greenschist facies foliation (Fig. 5h). The strain increase is visible close to the contact with adjacent lithotypes, producing mylonites (several kilometres in length; Fig. 4; Online Resource 1) with greenschist facies assemblages. The banded lithotypes have been termed "red schists" because of their characteristic weathering (e.g. Bertolani 1964; Dal Piaz et al. 1971, 2010; Dal Piaz 1976; Manzotti et al. 2014a, b).

Pre-Alpine assemblages are well preserved in central parts of the bigger lenses (Mont Nery, Corno del Lago, M. dell'Aquila; Stünitz 1989).

By relying on the main trails of the $2 \mathrm{DK}$ and the greenschist facies mylonites associated with these, the External Complex can be subdivided into two series of discontinuous lenses of 2DK, several kilometres in scale, termed respectively Aquila-Lago slice and Nery-Torché slice, and three tectonic sheets, the Crabun, Dondeuil and Chasten sheets, composed mainly of leuco- to mesocratic orthogneiss with minor paragneiss (Fig. 5e g).

In the External Complex meta-sedimentary trails are rare and range from 1 to $20 \mathrm{~m}$ in thickness. Near Arnad they comprise paragneisses and calc-micaschists with an impure quartzite band (Online Resource 1); north of Champurney the sequence involves paragneiss, impure quartzite, and an impure marble. South of Fornelle, in similar sequences Beltrando et al. (2014) described metacherts (ca. $1 \mathrm{~m}$ thick) occurring in contact with overlying gneiss. These meta-sediments do not contain any HT relics indicating a polycyclic history, and Dal Piaz et al. (1971, p. 263) proposed that they probably mark a dismembered Mesozoic cover. Nonetheless, because of their sparseness and lack of lateral continuity, we have not used them for further tectonic subdivisions.

\section{Metamorphic and structural evolution}

The metamorphic and structural evolution of the two complexes (Table 2) presented here is based on detailed field work, microstructural and petrographic analyses. Measured fabric orientations for each stage are shown in Table 3. Note that early structural and metamorphic stages recognised in the two complexes are numbered from 1 to 3 , but no correlation or synchronicity is implied prior to the juxtaposition of the two complexes, i.e. stage 4 .

\subsection{Internal complex}

\subsubsection{Stage 1, pre-Alpine high-temperature}

Pre-Alpine HT relics have been described in earlier studies, notably from the Mt. Mucrone area (Dal Piaz et al. 1972, Compagnoni 1977; Zucali et al. 2002); these include Pl, red $\mathrm{Bt}$, Grt and Sil, Or, and seldom Wm, but these have been observed but sparsely in the samples studied here.

In the Internal Complex pre-Alpine HT relics are occasionally visible (Fig. 3c). In micaschists porphyroclastic Grt cores, with a bright appearance in the optical microscope, occur rimmed by Alpine generations, which appear dark due to tiny inclusions of mostly Rt (Fig. 6a). In metabasic rocks rare pre-Alpine $\mathrm{Hbl}$ and $\mathrm{Pl}$ (with polysynthetic twinning) are preserved, reflecting amphibolite facies conditions (Fig. 3c) especially at Croix Courma, as previously noted by Compagnoni (1977) and Gosso et al. (2010). In orthogneiss the only magmatic relic observed is brown pleochroic Aln (Fig. 3c). Castelli (1991) described Cpx relics from the marble lens of Fontainemore (Type 1) indicating pre-Alpine HT conditions.

\subsubsection{Stage 2, Alpine eclogite facies}

Stage 2 comprises different stages at eclogite facies conditions, the main fabric element of which is an eclogitic foliation (S2) visible and measurable all along the Internal Complex. S2 is marked by alignment of $\mathrm{Wm}, \mathrm{Qz}, \mathrm{Zo}, \pm \mathrm{Gln}$ $\pm \mathrm{Omp} \pm \mathrm{Jd} \pm \mathrm{Grt} \pm \mathrm{Rt} \pm$ Cld (Figs. 3b d, 6b). S2 wraps rootless fold hinges (cm-scale) that reflect earlier deformation recognisable only locally at the microscale (Fig. 6b). S2 shows dips to the NW at moderate angle (Table 3), but due to subsequent deformation phases the S2 poles show dispersion. This foliation is subparallel to a compositional layering (e.g. felsic and basic bands in micaschists). S2 is associated with mylonitic fabrics over a distance of $4 \mathrm{~km}$, observed over several hundred metres 
Table 2 Summary of metamorphic and deformational stages of the two Complexes and the Barmet Shear Zone

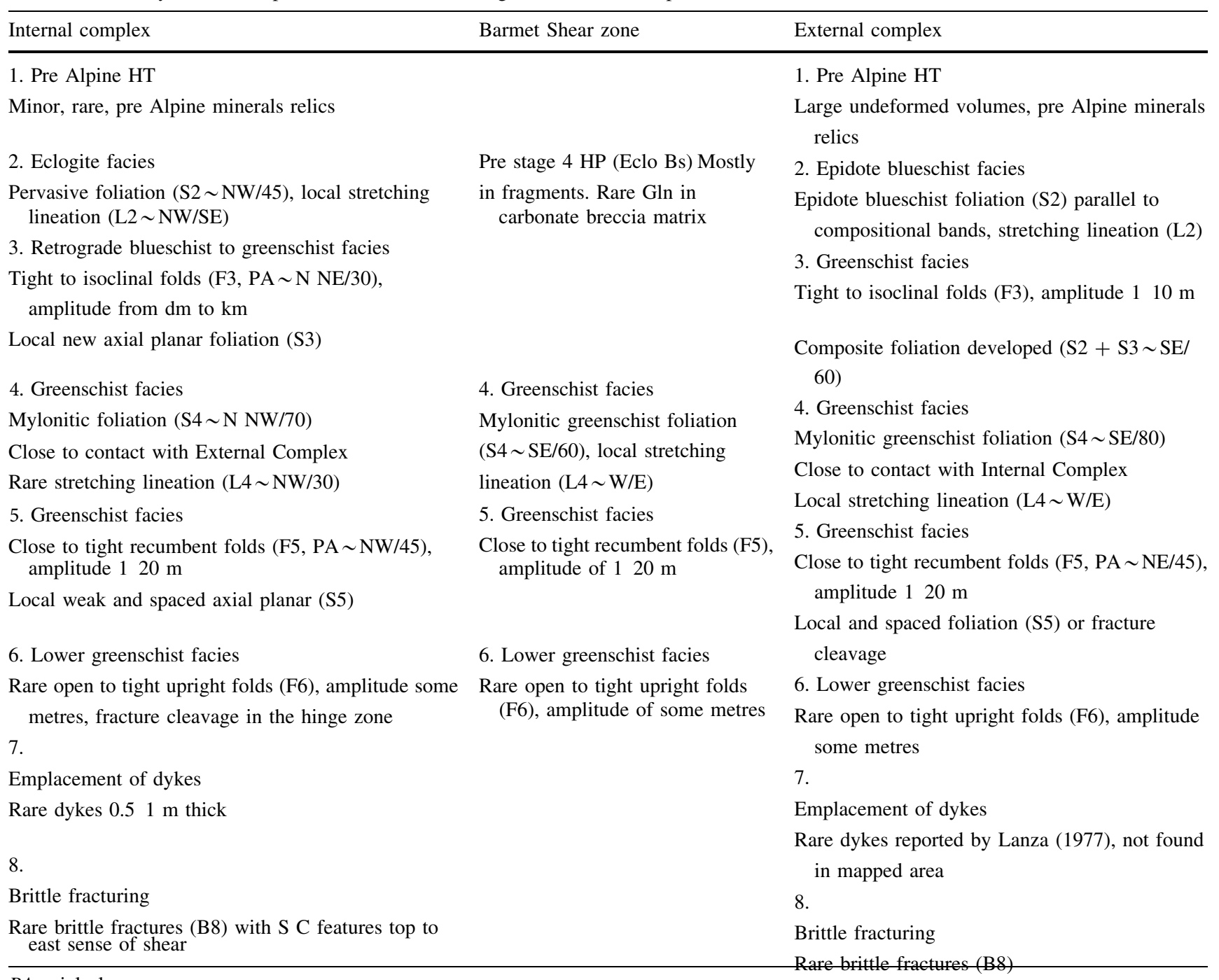

$P A$ axial planes

between Mont de Prial and the area SE of Cime P. Blanches.

Locally, a stretching lineation L2 marked by Gln \pm Omp $\pm \mathrm{Qz} \pm \mathrm{Zo}$ is observed, showing NW SE trends (e.g. South of Cime P. Blanches; Fig. 4; Table 3).

\subsubsection{Stage 3, retrograde blueschist to greenschist facies}

This deformation stage affected the main eclogitic foliation S2, producing tight to isoclinal F3 folds with an amplitude from $\mathrm{dm}$ to $\mathrm{km}$ (in the case of the Donnas fold; Figs. 4, 6c, d, 9) and an axial-planar parallelization of the previous eclogitic foliation, S2. Locally a new axial planar foliation S3 developed; it is marked by $\mathrm{Wm}$ and $\mathrm{Qz} \pm$ recrystallized Gln (recognized only at the microscale). These minerals also crystallized in dilatation sites of fold hinges. In thin section, Omp is observed to be fractured in hinge zones and is partially retrogressed to green Amp. Table 3 shows that the F3 fold axes were dispersed by subsequent deformation stages, and axial planes dip NE at low angles.

\subsubsection{Stage 4, greenschist facies}

A greenschist facies overprint variably affects the S2 eclogitic foliation, with a regional gradient from weak to strong going from $\mathrm{E}$ to $\mathrm{W}$, i.e. from internal to external parts of the complex. The overprint is mostly static in internal parts; it created coronae of Ep and $\mathrm{Czo}$ around $\mathrm{Zo}$ or metamorphic Aln, Chl rims on Grt, and green Amp or Chl \pm $\mathrm{Ab}$ grew at the expense of Gln and Omp. Pseudo-morphs acquire an earthy aspect resulting from finely 
Table 3 Orientation of fabric elements, associated metamorphic facies (purple: eclogite facies, light blue: epidote blueschist facies, dark blue: non specifiable HP conditions) and their relative chronology

INTERNAL COMPLEX
BARMET SHEAR ZONE
EXTERNAL COMPLEX

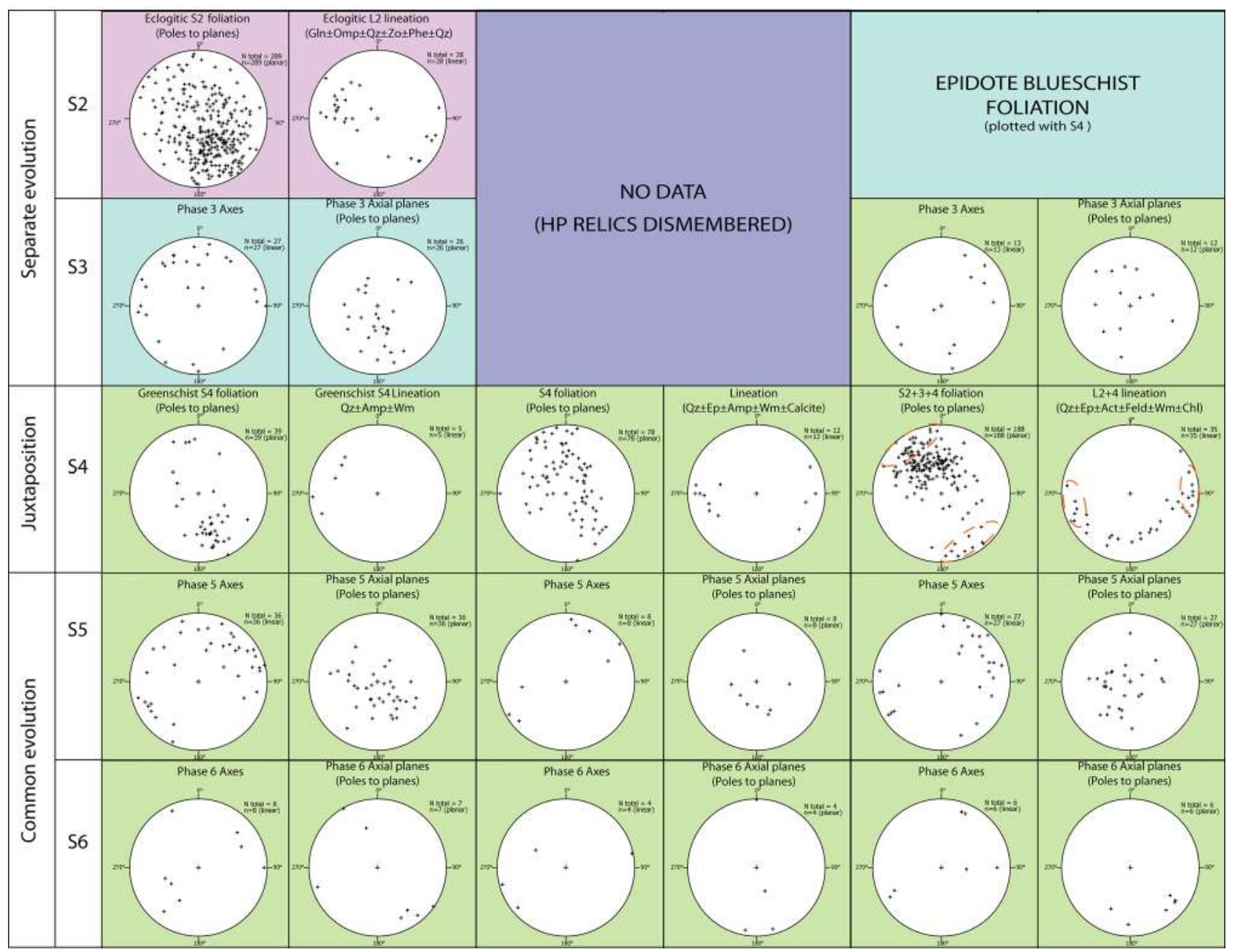

For the External Complex, stage 4 values related to S4 and L4 are highlighted by dashed line ellipses. Equal area projection, lower hemisphere (Stereo 32 software used). Note that early structural and metamorphic stages recognised in the two complexes are numbered from 1 to 3 , but no correlation or synchronicity is implied prior to the juxtaposition of the two complexes, i.e. stage 4

intergrown green $\mathrm{Amp} \pm \mathrm{Ab}$, and Rt is rimmed by Ttn that is in turn locally rimmed by Ilm.

A greenschist S4 foliation developed close to the contact with the External Complex; in some places it is mylonitic, dipping NW at moderate to high angles (Table 3). S4 is marked by Qz, Ab, Ep, Wm, Chl, green Amp and Ttn. Normally, this new foliation weakly overprints the previous HP fabric, but very intensely where a mylonitic fabric developed (e.g. NW of Albard; Fig. 4; Online Resource 1). Few L4 stretching lineations are visible, marked by Qz, Amp and $\mathrm{Wm}$, they trend $\mathrm{W}-\mathrm{NW}$ at moderate-low angles.

\subsubsection{Stage 5, greenschist facies}

This deformation stage produced close to tight F5 folds, with amplitudes ranging from 1 to $20 \mathrm{~m}$, affecting the eclogite S2 foliation and, where present, the greenschist S4 foliation (Fig. 6e, f). Wm shows oscillatory extinction in hinge zones, and $\mathrm{Qz}, \mathrm{Ab}, \mathrm{Wm}$, and $\mathrm{Chl}$ crystallized in the dilatation sites of F5 fold hinges. Locally (e.g. west of Donnas) a weak and spaced axial planar S5 foliation developed, defined by $\mathrm{Wm}, \mathrm{Ab}, \mathrm{Chl}$, and green Amp. F5 fold axes trend NE-SW, axial planes dip NE at low angle. 


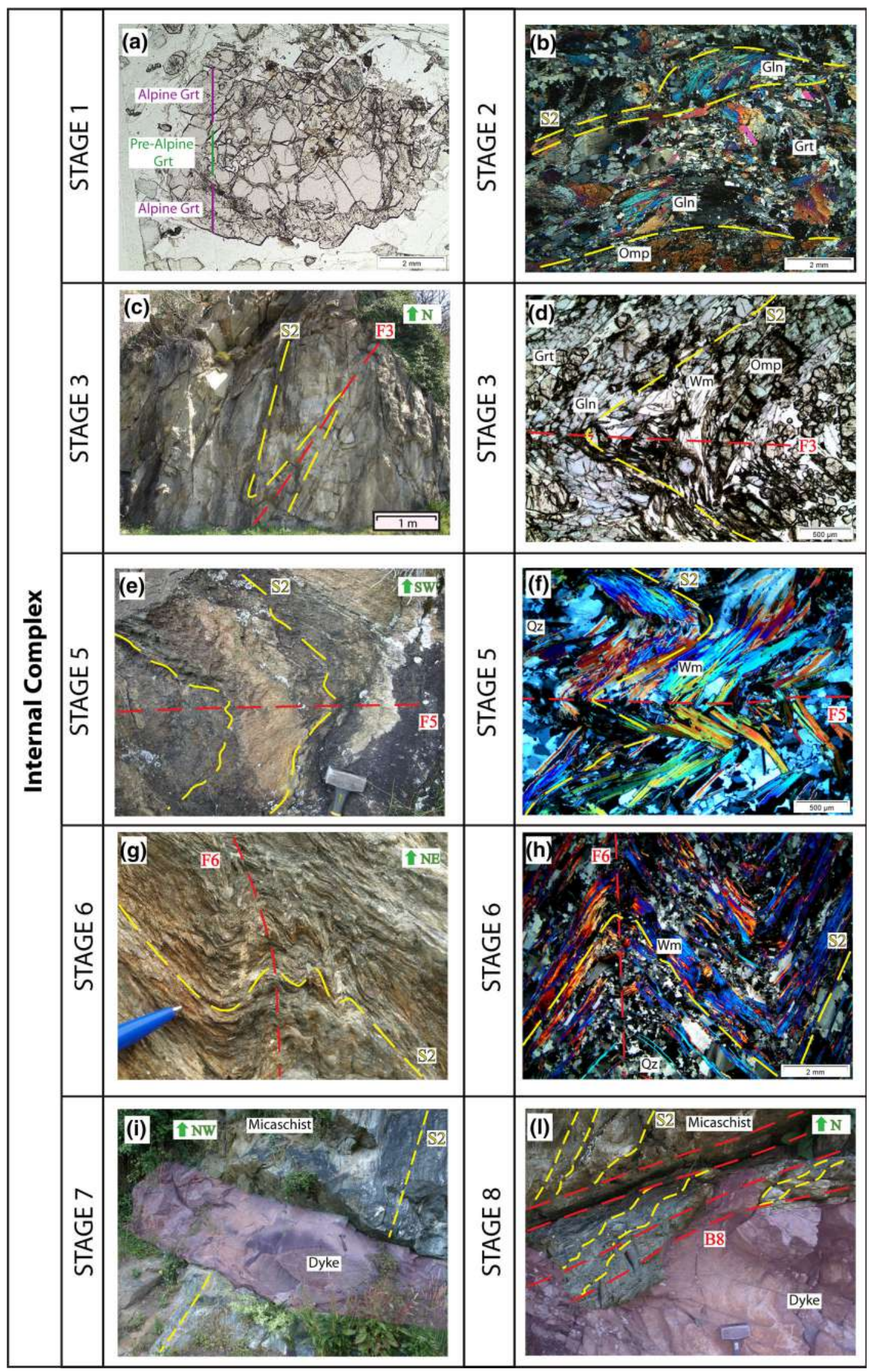


4Fig. 6 Main deformation stages in the Internal Complex: a Poly metamorphic garnet with a light pre Alpine core and a cloudy Alpine rim (stage 1, Croix Courma sheet; plane polarized light). b Micaschist with S2 marked by Omp, Gln and Wm wrapping around earlier Gln crystals disposed at high angle (Loses Blanches sheet; crossed polarized light). c Several metres F3 isoclinal fold in orthogneiss (Internal Complex). d Photomicrograph of F3 hinge zone in which omphacite shows undulose extinction (Loses Blanches sheet; plane polarized light). e F5 fold in rusty fine grained micaschist (Loses Blanches sheet). f F5 hinge zone with recrystallized phengite (Loses Blanches sheet; crossed polarized light). g F6 hinge zone (cm size) in fine grained micaschist (Croix Courma sheet). h F6 hinge zone with phengite showing undulose extinction and kink geometry with fractures (Croix Courma sheet; crossed polarized light). i Dyke (highlighted in purple) cutting the $\mathrm{S} 2$ foliation; outcrop close to Marine village,; orientation of the contact: 355/35 (Croix Courma sheet). 1 Dyke (highlighted in purple) emplaced inside a micaschist with S2 foliation; outcrop north of Albard di Bard. Brittle fractures (S8) crosscut both dyke and micaschist (Croix Courma sheet). Field photos coordinates are included in Online Resource 3

\subsubsection{Stage 6, lower greenschist facies}

In few areas (e.g. south of Chousette; Online Resource 1) open to tight F6 folds with a sub-vertical axial plane are visible; in thin section $\mathrm{Qz}$ and $\mathrm{Wm}$ recrystallized in triangular sites located in hinge zones (Fig. 6g, h). This deformation stage produced no axial plane foliation but locally a fracture cleavage is visible in the hinge zone. F6 axial planes strike NE-SW, and fold axes show a similar trend.

\subsubsection{Stage 7, emplacement of dykes}

Rare dykes (typically $0.51 \mathrm{~m}$ thick; e.g. north of Albard, east of Marine; Fig. 4) crosscut structural elements of all previous stages. They dip $\mathrm{N} \mathrm{NW}$ at moderate angles (Fig. 6i 1).

\subsubsection{Stage 8, brittle deformation (Vanzone fold phase?)}

Rare brittle fractures (B8) with several millimetres to centimetres $\mathrm{S}-\mathrm{C}$ features crosscut a dyke north of Albard de Bard. These planes dip toward NW at low angle and show top to east sense of shear (Fig. 61).

\subsection{External complex}

\subsubsection{Stage 1, pre-Alpine}

In central parts of the Aquila-Lago and Nery-Torché slices, pre-Alpine HT metamorphic relics are common, i.e. Grt, Pl and $\mathrm{Bt}$ in paragneiss; Amp, $\mathrm{Pl} \pm \mathrm{Cpx}$ in amphibolites and granulites (e.g. east of Crabun and Mt. Nery; Figs. 3c, 7a).

In the Crabun and Chasten sheets pre-Alpine metamorphic green brown $\mathrm{Hbl}$ is preserved in amphibolites west of
Machaby and also to the east of Col Chasten (Fig. 3c; Online Resource 1).

In the Crabun, Chasten and Dondeuil sheets, magmatic relics are observed in orthogneiss, notably Kfs, brown pleochroic Aln, and Ap (Figs. 5e, 7b).

\subsubsection{Stage 2, Alpine, epidote blueschist facies}

Rootless fold hinges at $\mathrm{cm}$-scale reflect earliest deformation. They are grouped into stage 2, as they are recognisable at microscale only. Similarly, an early internal foliation observed in Grt grains ( $\varnothing \mathrm{mm}-\mathrm{cm}$ ), marked by Qz, Ep, Ttn, is included in this stage. This early Grt occurs in orthogneiss bands (1 $100 \mathrm{~m}$ thick) in the Crabun sheet, E of Mt Crabun peak, E of Le Mériou and also W of Albard de Bard (Figs. 4, 5f). In the Mt Crabun area the garnet-bearing orthogneiss displays sparse metamorphic Aln as rims on magmatic Aln and in cores of Czo Ep.

During stage 2 a foliation developed, oriented parallel to compositional bands in layered rocks, and marked by $\mathrm{Ab}$, Qz, Wm, Chl, Ep \pm green blue Amp \pm Ttn. S2 dips moderately to steeply SE (Table 3 ). This stage pervasively affects the Crabun, Chasten and Dondeuil sheets. It shows a mylonitic fabric, notably near Chavanisse, Champurney, Machaby, and generally close to contacts between orthogneiss and 2DK slices (e.g. Aquila-Lago and NeryTorché; Fig. 4; Online Resource 1). The mylonitic fabric reflects significant grain size reduction in a strain gradient.

A stretching lineation L2 is rarely observed on the S2 foliation. It is marked by $\mathrm{Qz} \pm \mathrm{Ep} \pm \mathrm{Act} \pm \mathrm{Ab} \pm$ $\mathrm{Wm} \pm \mathrm{Chl}$, dips are mainly $\mathrm{S} \mathrm{SE}$ at moderate angles (Table 3).

Green blue Amp is locally observed in sparse basic boudins in the Chasten sheet (close to Arnad), reflecting metamorphic conditions at HP greenschist or at most epidote-blueschist facies at this metamorphic stage. In orthogneiss close to Col Chasten rare Rt crystals were noted at the core of Ttn.

\subsubsection{Stage 3, greenschist facies}

In the entire External Complex, the main foliation S2 is tightly folded, at metre to decametre scale, thus $\mathrm{S} 2$ is usually subparallel to the F3 axial plane (Fig. 7c, d). In the hinge zone the previous $\mathrm{Wm}$ recrystallized, and a new greenschist S3 developed marked by Wm, Chl, Ep \pm green Amp \pm Ttn. Due to the same orientation in the field and similar mineral content, S2 and S3 are indistinguishable except in hinge zones. Hence a composite foliation was mapped (stages $2+3$ foliation). F3 fold axes trend NE-SW; F3 axial planes are dispersed, a data maximum shows SE dips at moderate angles (Table 3). 


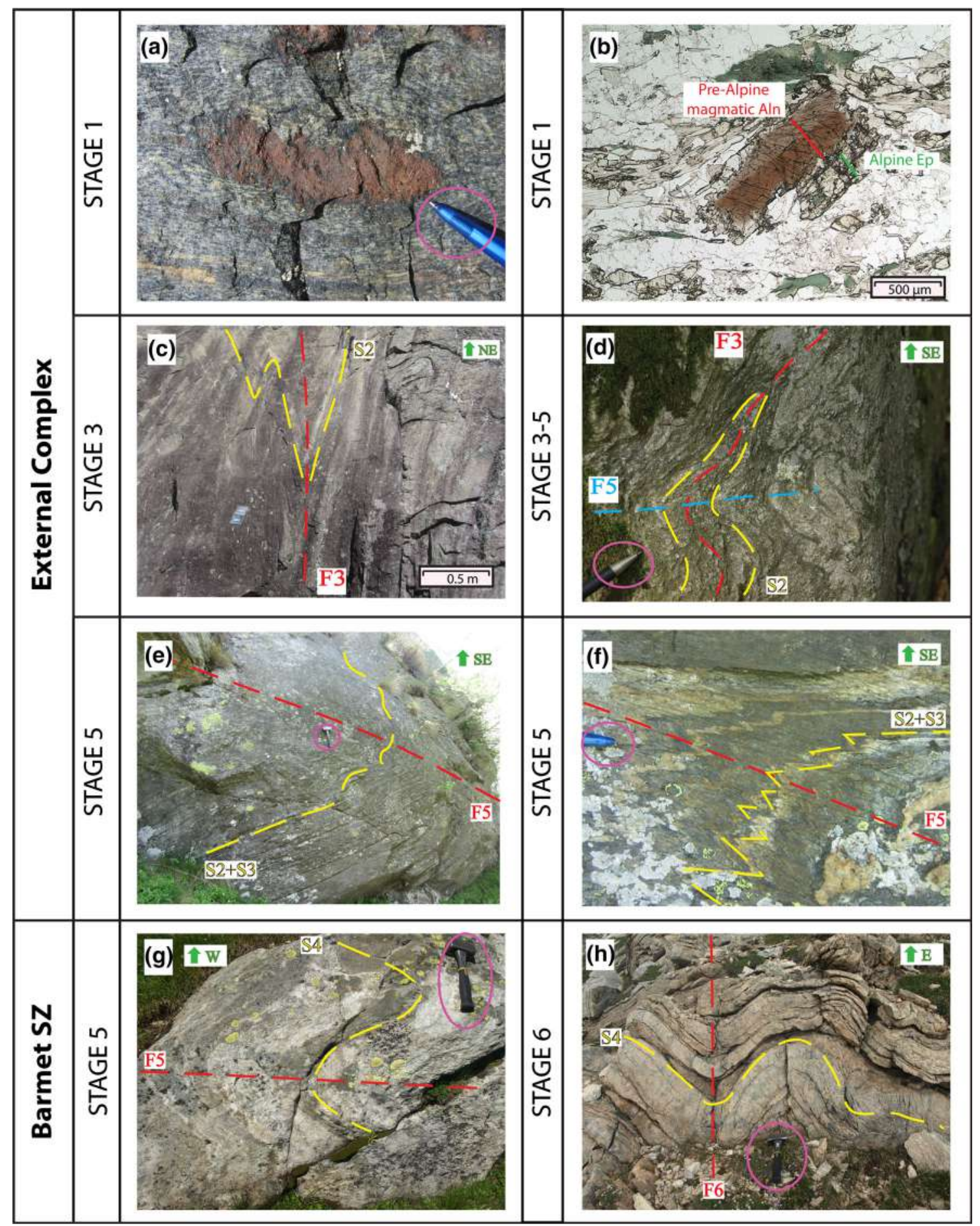

Fig. 7 Main deformation stages in the External Complex and in the BSZ. a Pre Alpine Grt aggregate $(10 \mathrm{~cm} \varnothing)$ in amphibolite. The HT foliation is preserved. (2DK, boulder in the scree from the Nery Torché slice). b Pre Alpine magmatic allanite displaying simple twinning in orthogneiss (Dondeuil sheet; plane polarized light). c Several metres F3 isoclinal fold in the orthogneiss (Crabun sheet). d Intersection pattern between $\mathrm{cm}$ scale F3 and F5 in paragneiss
(Crabun sheet). e Several metres F5 fold in orthogneiss (Crabun sheet). f F5 detail with crenulation cleavage in paragneiss (Crabun sheet). g Metre scale F5 hinge zone in orthogneiss (Barmet SZ). h F6 hinge in silicate marble with associated fractures (Barmet SZ). Pink circle highlight the scale. Field photos coordinates are included in Online Resource 3 


\subsubsection{Stage 4, greenschist facies}

A mylonitic foliation S4 developed along the contact between the Internal and External Complexes. In the southern part of the External Complex, it lies at small angles with the previous composite $\mathrm{S} 2+\mathrm{S} 3$ foliation and is defined by the same metamorphic minerals as stage 3 . For these reasons data are plotted with the previous com-posite foliation and are highlighted in the stereographic projection by dashed ellipses. S4 dips NW and SE at high angles (Table 3). A L4 lineation is locally observed, marked by the same minerals as L2. For this reason data for L2 and 4 are plotted together in Table 3, and the latter are highlighted by dashed ellipses. L4 trends E W at low angles. S4 and L4 are the first common structural elements observed in both the Internal and External Complexes, hence stage 4 probably is related to their juxtaposition. Subsequent stages, described below, correspond to those described for the Internal Complex.

\subsubsection{Stage 5, greenschist facies}

In the entire External Complex, this stage produced close to tight F5 folds reorienting the foliations S2, S3, and S4. $\mathrm{Qz}, \mathrm{Ab}, \mathrm{Chl}$, green Amp $\pm \mathrm{Wm}$ mainly (re)crystallize in dilatation sites of hinge zones, thus developing a local spaced S5 foliation or a fracture cleavage (SE of Machaby; Fig. 7d f). F5 fold axes trend NE-SW, and F5 axial planes dip $\mathrm{E} \mathrm{NE}$ at low to moderate angles (Table 3). As F5 deformed the contact between the two complexes, stage 5 deformation is thought to postdate their juxtaposition and thus to be coeval in both.

\subsubsection{Stage 6, lower greenschist facies}

Rare open to tight F6 folds (e.g. N of Cime P. Blanches) with sub-vertical F6 axial planes and amplitudes of some metres deform the fabrics of previous phases. No new minerals seem to have crystallized during this late stage. F6 axes and axial planes display a NE SW strike.

\subsubsection{Stage 7, emplacement of dykes}

Rare occurrences of andesitic and lamprophyric dykes are described by Lanza (1977) but none of these were observed in the study area.

\subsubsection{Stage 8, brittle fracturing (Vanzone fold phase?)}

Rare brittle fractures (B8; e.g. SW of Tête de la Cou), similar to the ones of the Internal Complex, are visible in the panorama.

\section{The Barmet Shear zone (BSZ)}

\subsection{Geometry and lithotypes of the BSZ}

The contact between the Internal and External Complexes is marked by the Barmet Shear Zone (hereafter BSZ), the structural expression of which is a S4 pervasive greenschist facies foliation with mylonitic features in several places (i.e. between north of Bard and Verale, Pian Dzen and Cime P. Blanches; Figs. 3b, 4; Online Resources 1, 5, 6). This tectonic contact delimits areas with a different max-imum metamorphic imprint: The Internal Complex reached eclogite facies, whereas the External Complex reached HP greenschist to epidote blueschist facies. This is evident in Fig. 3d, depicting the distribution of the HP minerals. The BSZ surfaces between Pont de Trenta and Hône, across the entire area mapped; it is wedged between the two complexes with a thickness of several hundred metres. While it does not outcrop from Mont Fenêtre to Col de la Cou, the contact zone is readily traceable on the basis of the different lithotypes in the Internal and External Complexes, i.e. eclogite facies micaschist (locally retrogressed) against greenschist facies orthogneiss (Fig. 4; Online Resource 1).

Descending towards the Aosta Valley the contact is more difficult to delineate owing to the stronger greenschist facies overprint (S4) in the Internal Complex. However, almost down to Albard di Bard, eclogite bands and eclogite facies relics are locally observed in the Internal Complex (Fig. 3d). Based on these observations, the contact appears to become sub-vertical and finally dips NW. From the village of Albard down to the bottom of the Aosta Valley the contact is difficult to identify, as the juxtaposed litho-types are similar (mostly orthogneiss with a pervasive greenschist facies overprint, in both the Internal and External Complexes; Fig. 4; Online Resource 5).

The best section to observe the BSZ is between Vallon de Scheity and Torrent de $\mathrm{Va}$, in the Crabun-Prial area (Figs. 4, 8, 9; Online Resource 6). There the BSZ is lenticular in shape, with a maximum thickness of $\sim 500 \mathrm{~m}$ (across the main foliation). Its width decreases sharply towards NE, where it disappears below the Vallon the Scheity landslide deposits, and to the SW, where it outcrops with a reduced thickness of 50 metres on the ridge north of Cime P. Blanches (Figs. 4, 9).

In the Crabun-Prial area, the BSZ shows siliceous dolomite marbles wrapping blocks, boudins and slices, from centimetre to several hundred of metres thick, of ortho- and paragneiss with minor metabasite (Fig. 8a).

The marbles show a thickness from metres to several decametres and variable degrees of dolomitization; yellow weathering is characteristic. Bands of pure marble with a sugary texture occur (e.g. at Pian Dzen, Fig. 4). Meta- 

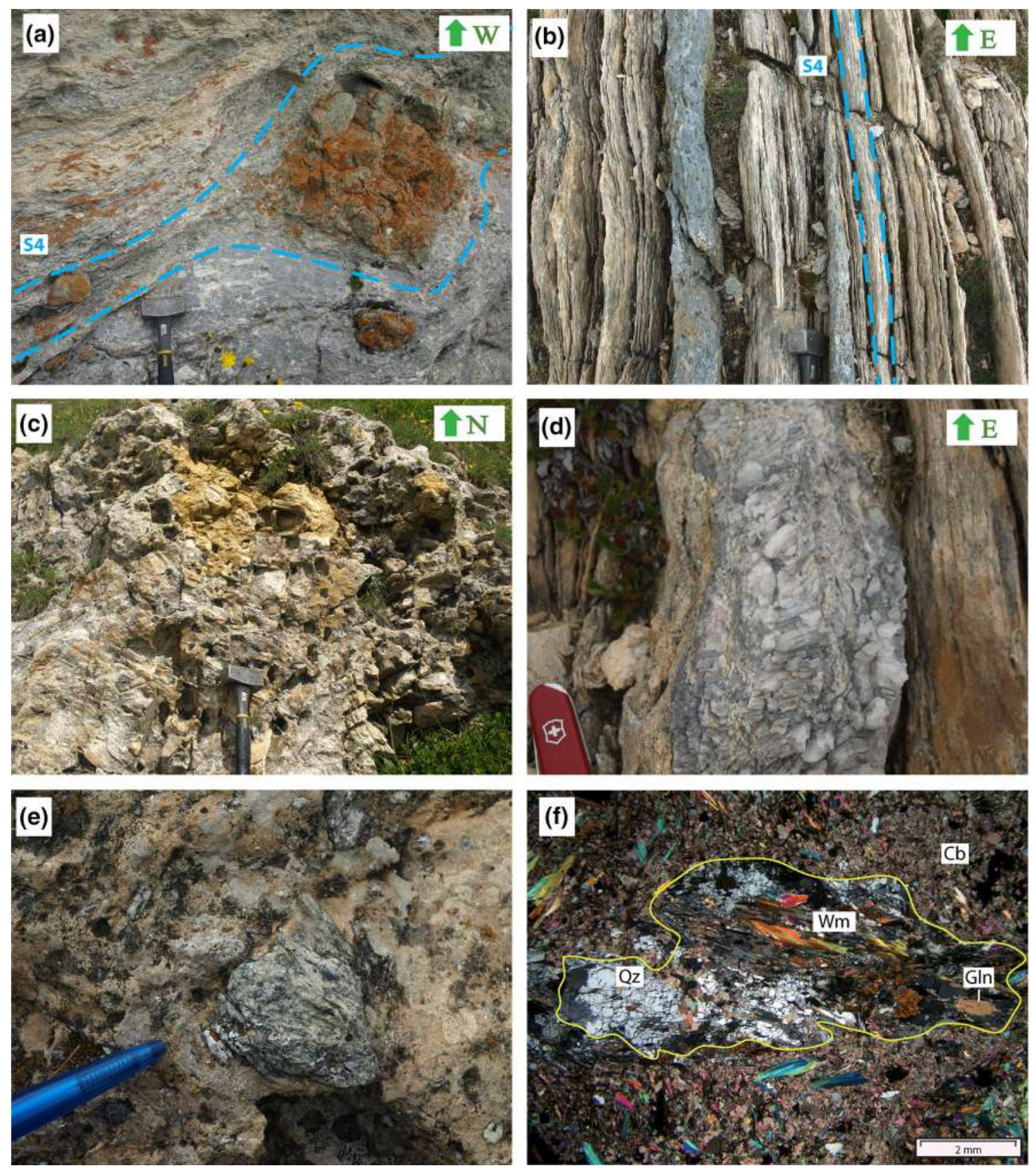

Fig. 8 Lithotypes of the Barmet Shear Zone. a Marble with metabasite boudins wrapped by the $\mathrm{S} 4$ greenschist foliation). b Silicate marbles with basic bands displaying a mylonitic foliation (S4) at Cime P. Blanches. c Cornieule with $\mathrm{cm}$ size cubic or parallelepipedal holes possibly after former sulphate (W of Mt. Prial). d Boudins containing long prisms of white carbonate, probably calcite

basites commonly occur in bands, $520 \mathrm{~cm}$ thick (e.g. Cime P. Blanches), and in boudins within the marbles oriented parallel to the main foliation (S4, Fig. 8a, b). Rare eclogite fragments are found in impure marbles; their shape varies from rounded to angular, their size from a few centimetres to a metre.

pseudomorphic after aragonite (Cime P. Blanches). e Carbonate breccias with Gln gneiss clast (W of Mont the Prial) $\mathbf{f}$ Matrix rich in carbonate and phengite surrounding a Gln micaschist (crossed polarized light). Field photos coordinates are included in Online Resource 3

The BSZ is delimited to the east by a conspicuous band of cornieules several metres thick (Fig. 4). The rocks are massive, intensely yellow in weathering colour, and display holes ( $\mathrm{cm}$ to $\mathrm{dm}$ in size) with parallelepipedal to cubic shapes possibly reflecting the presence of former sulphates or halides (Fig. 8c, e.g. Jeanbourquin 1988). 


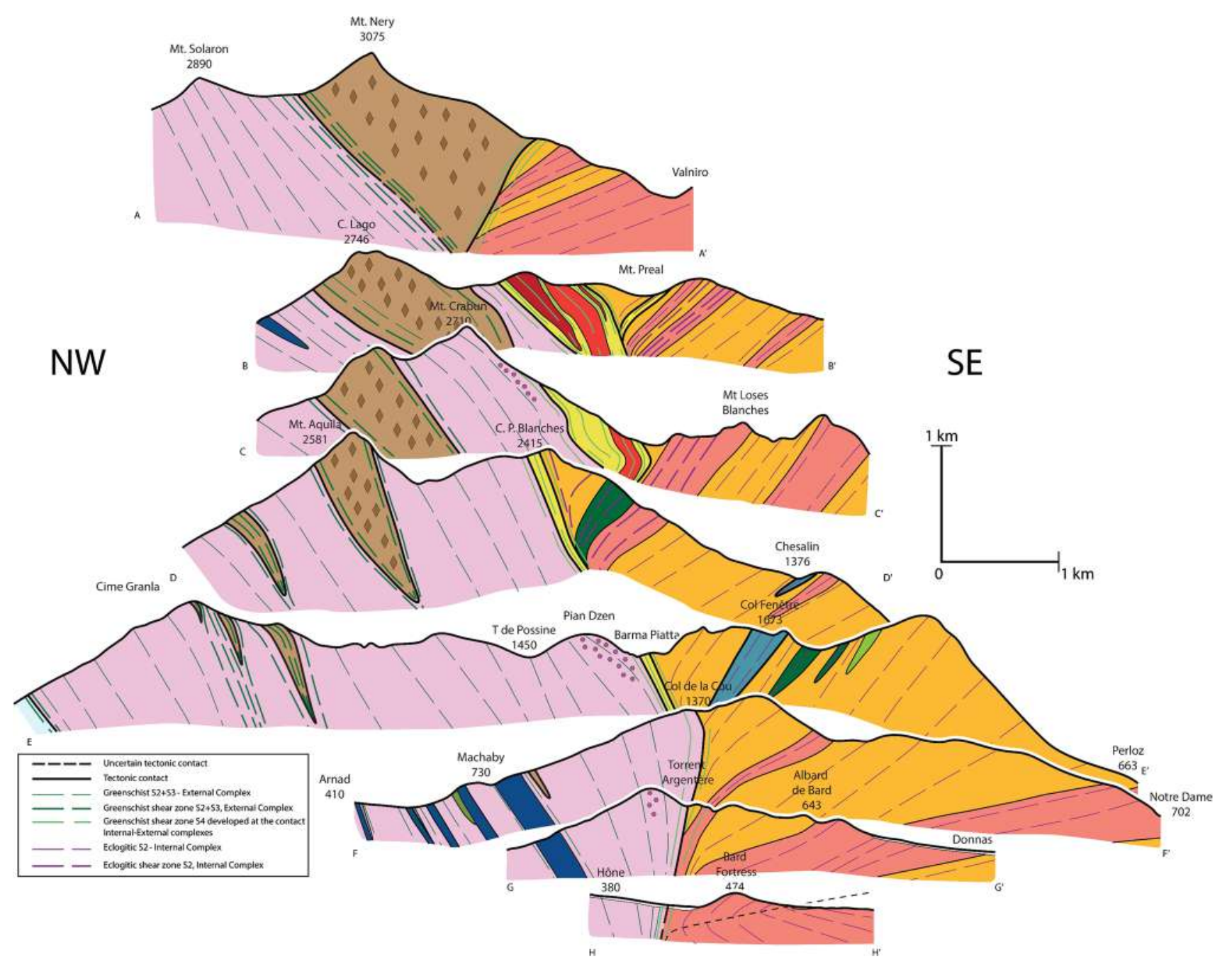

Fig. 9 Cross sections (location and legend in Fig. 4 and Online resource 1)

To the north of these cornieules, carbonate breccias crop out $\mathrm{W}$ of Mont the Prial with a thickness of few metres (Figs. 8e, f). They are massive and composed of a matrix rich in carbonate and Wm plus minor Gln; fragments (from $\mathrm{mm}$ to several $\mathrm{cm}$ in size) include Gln gneisses and micaschists.

\subsection{Metamorphic and structural evolution of the BSZ}

\subsubsection{Pre-stage 4, high pressure relics}

Several HP relics are found in the BSZ. Because the related fabric elements are visible at cm-scale only, mostly preserved in fragments or boudins, orientations could not be measured; the relics are grouped as a single stage. Inside the marbles, rare boudins containing long prisms of a white carbonate mineral are visible at Cime P. Blanches (Fig. 8d). These probably are intergrowths of $\mathrm{Cal}$ pseudomorphic after Arg, which are commonly preserved in HP-LT terrains and are observed also near Quincinetto (lower Val d'Aosta; Compagnoni et al. 2014).

In meta-diorite blue Amp is visible, though it is but rarely preserved in the core of $\mathrm{Chl} \pm$ green $\mathrm{Amp} \pm \mathrm{A}$ $\mathrm{b} \pm$ Ep pseudomorphic aggregates (stage 4); Rt is rimmed by Ilm. The basic boudins in meta-diorite display Omp that appears mottled, in thin section, and is overgrown by pale green to colourless $\mathrm{Amp} \pm \mathrm{Ab}$ (associated with stage 4).

Clasts in the carbonate breccia appear randomly oriented, as shown by their internal HP foliation, which is marked by Gln and Wm (Fig. 8e, f).

\subsubsection{Stage 4, greenschist facies}

The marbles show an intense to mylonitic S4 foliation (stage 4; Fig. 8a, b). Typically they are silicate-rich with layers of $\mathrm{Wm} \pm \mathrm{Tr} \pm \mathrm{Tlc} \pm \mathrm{Ab} \pm \mathrm{Ep} \pm \mathrm{Ttn}$ in dolomiterich bands. 
The pervasive foliation $\mathrm{S} 4$ is of greenschist facies; it shows gentle dips toward SE and NW (Table 3). S4 is marked by $\mathrm{Ab}, \mathrm{Qz}, \mathrm{Wm}, \mathrm{Chl}, \mathrm{Ep} \pm$ green $\mathrm{Amp} \pm \mathrm{Ttn}$ in meta-granitoids and in paragneiss; in the impure marbles S4 is defined by $\mathrm{Wm} \pm \mathrm{Tr} \pm \mathrm{Tlc} \pm \mathrm{Ab} \pm \mathrm{Ep} \pm \mathrm{Ttn}$. Mostly, mylonitic features are common. An associated L4 stretching lineation trends $\mathrm{E}-\mathrm{W}$ and is marked by $\mathrm{Wm} \pm \mathrm{Tr}$. The BSZ cuts the main eclogitic foliation (S2) of the Internal Complex, as well as the km-scale F3 fold visible between the villages of Donnas and Bard (Figs. 4, 9). A small discordance is noted between the composite $\mathrm{S} 2+\mathrm{S} 3$ of the External Complex and S4 foliation.

\subsubsection{Stages 5, greenschist facies}

The contacts of the BSZ to the two Complexes is folded by the F5 folds (Fig. 7g), corresponding to F5 seen in the Internal and External Complex. A remarkable change results in the orientation of the contacts. Specifically, the BSZ dips toward NW between Pont de Trenta and Vallon de Stolen at moderate angles, it changes orientation and dips $\mathrm{SE}$ at moderate angles from the Crabun Prial ridge to Pian, where it turns much steeper $\left(>80^{\circ}\right)$ up to Cime P. Blanches (Online Resource 1; Fig. 4). SW of Cime P. Blanches the strike remains similar, but the dip becomes sub-horizontal at Pian Dzen, but turning steeper again further south (around $60^{\circ}$ to the west of Mont Fenêtre), and dipping NW again at high angles south of Col de la Cou.

\subsubsection{Stages 6, lower greenschist facies}

Rare open to tight F6 folds e.g. (N of Cime P. Blanches) with sub-vertical F6 axial planes and amplitude of some metres deform the fabrics of previous phases (Fig. 7h). No new minerals seem to have crystallized during this late stage, which again corresponds to stage 6 in the Internal and External Complexes.

\section{Discussion}

\subsection{Assembly and geometry of the central Sesia Zone}

\subsubsection{The Barmet Shear zone}

The presence of marble along the contact between the Internal and External Complexes was already noted by Passchier et al. (1981) and Vuichard (1989), with the adjacent terranes denoted EM and GM, but the section between Mont Crabun and Prial had not been identified as a high-strain zone between the two complexes. This newly identified tectonic element is situated in a critical position and contains critical evidence to assess the juxtaposition of the Internal and External Complexes.

The BSZ is a wedge in which fragments and slices from $\mathrm{cm}$ to some hundreds of metres are incorporated in a carbonate matrix. According to the lithological features, fragments mostly derive from the Internal Complex, with only a minor part from the External Complex. In the central part of the newly mapped area, the tectonic contact is thus not as sharp and narrow as in the rest of the area, instead the shear zone incorporated fragments from both complexes that were sliced up and reworked in the carbonaterich wedge (Figs. 4, 9).

In this scenario, the carbonate breccias contain some important evidence: They show that brittle deformation occurred during an early stage of development of the BSZ (prior to stage 4), at HP conditions, since the breccias contain gneiss fragments with a HP foliation in a carbonate matrix with Wm and minor Gln. The Gln is the only evidence to indicate an early HP development of the Barmet SZ because all other HP relics are preserved only in fragments (slices or boudins) that may just reflect the conditions of their source units. After this HP stage, a pervasive and mostly mylonitic greenschist foliation developed (S4), which we view as related to the juxtaposition of the Internal and External Complexes. The BSZ is thus of pri-mary importance, reflecting the protracted juxtaposition of eclogite facies rocks, i.e. the Internal Complex, against the External Complex, which peaked at epidote blueschist facies.

Parenthetically, we note that eclogite breccias were described from the Monviso ophiolite, derived from the Piemonte-Ligurian Ocean (Angiboust et al. 2011, 2012). These consist of metagabbro clasts in a serpentinite matrix and were attributed to intermediate to deep earthquakes occurring in the subducting slab.

Fragments inside a carbonate matrix can be also produced in tectono-sedimentary settings, like close to a normal faulted basement in ocean-continent transition zone settings (e.g. Froitzheim and Manatschal 1996). This hypothesis seems unlikely for the formation of the above described carbonate breccia because of the well defined Alpine HP foliation in the siliceous clasts. This foliation cannot develop inside single clasts enveloped by a carbonate matrix due to the strong rheological contrast existing between the lithotypes involved.

A further noteworthy feature is the newly discovered cornieules at the eastern boundary of the BSZ; to our knowledge they had not been previously known in the central Sesia Zone. They are an important marker because, in association with siliceous dolomite, they indicate a Triassic origin of the sediments (Jeanbourquin 1988). The origin of the cornieules is not very clear, however; they may have been partially re-mobilized at the tectonic 




Fig. 10 Schematic sketch summarizing the deformative stages in the study area

contact and thus, in the terminology of some authors (e.g. Alberto et al. 2007; Fudral et al. 2010), they might be pseudo-cornieules.

\subsubsection{Proposed tectonic geometric model and comparison with previous tectonic models}

The structural characteristics of the study area, summarized in Fig. 10, are here compared with those in the schematic models discussed in Sect. 3.1 and are then integrated into a new geometric model (Fig. 11).

In Fig. 11, two stages are proposed: stage (a) is the structural setting after the Internal and External Complexes were juxtaposed (post stage 4 ). For this stage, fabric orientations were back rotated $\sim 40^{\circ}$ to $60^{\circ}$ counterclockwise based on Lanza (1977) and Berger et al. (2012a). Stage (b) is the present setting. We note that Lanza (1977) proposed a rotation of the Internal Complex relative to the (unrotated) External Complex, an interpretation that is at odds with the observations presented in this study.

We recognise two complexes (Internal and External) separated by a tectonic contact zone, the structural expression of which is a mylonitic greenschist facies foliation (S4) called the BSZ. The BSZ cuts the S2 foliation of the Internal Complex at an angle of circa $50^{\circ}$. In the southern part of the External Complex, S4 is subparallel or at a small angle to the composite foliation $(\mathrm{S} 2+\mathrm{S} 3)$, whereas in the northern part, S4 cuts at an appreciable angle both $\mathrm{S} 2+3$ and the lithological boundaries in the External Complex (Figs. 3, 4; Online Resource 1). This first order distinction concurs with the models b, $\mathrm{c}$ and $\mathrm{f}$ in Fig. 2 (references in Sect. 3.1), but it is at odds with models a and d. Inside the shear zone fragments and slices of the two complexes were incorporated in a carbonate matrix owing to ductile deformation preceded by one or more brittle stages that occurred at high pressure (prior to stage 4).

The Internal Complex is subdivided into three main eclogite facies sheets based on the presence of meta-sediments presumed to be monocyclic. This is in agreement with models e and g (Fig. 2), where such meta-sediments are regarded as nappe boundaries. However, we note that the nappe boundary in model $\mathrm{g}$, between the Mombarone and Bard units, is the Bonze unit (sensu Venturini et al. 1994) which lies in a position equivalent to the Col Fenêtre meta-sediments (Fig. 4). Based on the map presented in Fig. 4, these meta-sediments are situated inside the Internal Complex, where they mark the contact between the Loses Blanches and Croix Courma sheets. Therefore, the nappe boundary in model $\mathrm{g}$ does not correspond to the one between Internal and External Complexes as defined in this study. 


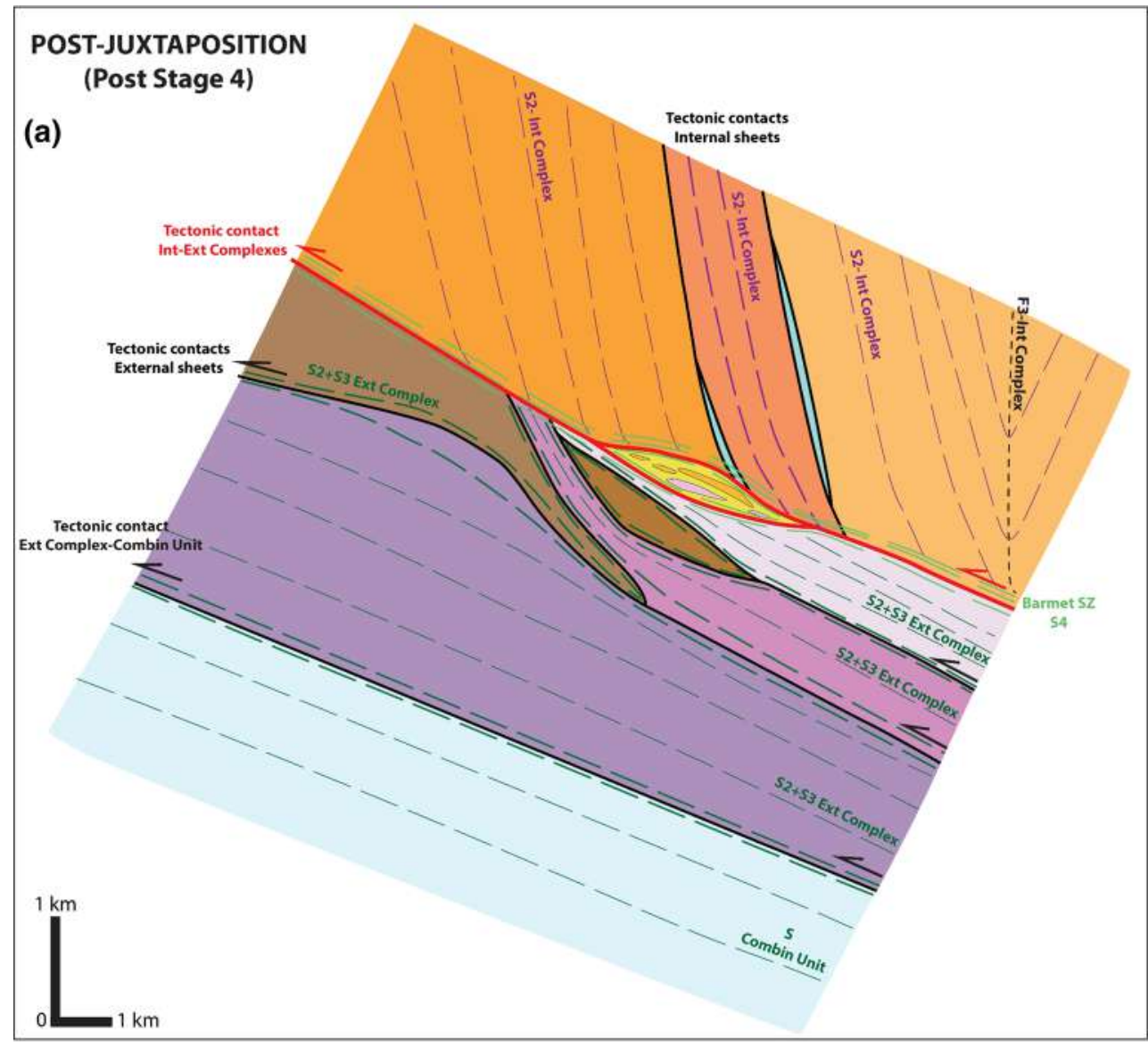

GEOMETRICAL MODEL
ADRIA-DERIVED SLICES
SESIA ZONE
EXTERNAL COMPLEX
Chasten sheet
2DK lithotypes-Nery-Torché slice
Dondeuil sheet
2DK lithotypes-Aquila-Lago slice
Crabun sheet
BARMET SHEAR ZONE
INTERNAL COMPLEX
Preal sheet
Loses Blanches sheet
Croix Courma sheet
Monometamorpic cover trails
PIEMONTE LIGURIA
OCEAN-DERIVED UNITS
Combin Unit

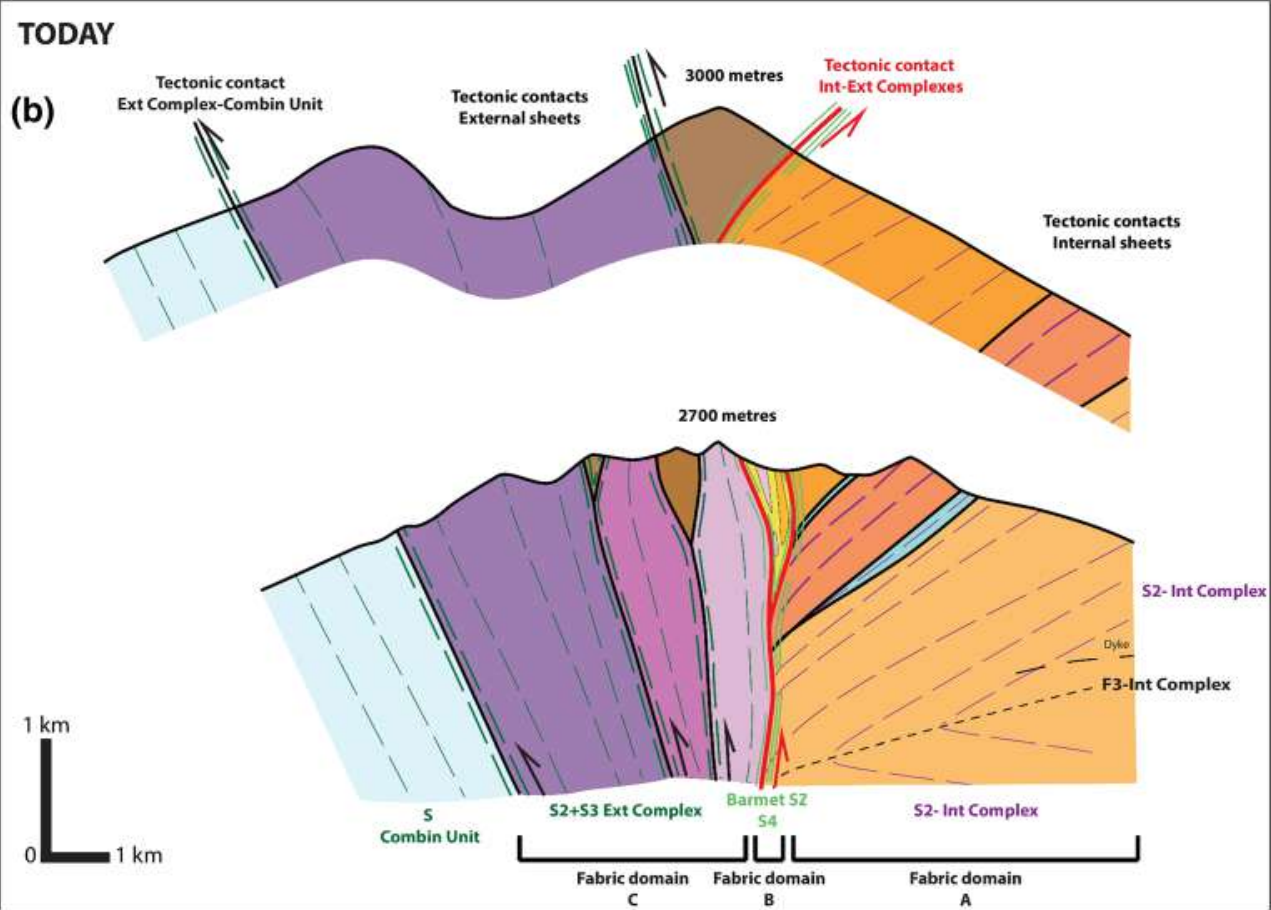

Fig. 11 Geometric model proposed for the study area. a Structural setting after the juxtaposition of the Internal and External Complexes (post Stage 4). b Present setting 
In the External Complex, slices of 2DK aligned along the greenschist facies shear zone $(\mathrm{S} 2+\mathrm{S} 3)$ are interleaved with three gneiss sheets. This is essentially in agreement with what model $b$ proposed. In the Mont Nery area, where the largest 2DK slice is in contact with the Internal Com-plex, we cannot exclude the possibility that the juxtaposi-tion of these bodies started in HP condition, as proposed in the models $\mathrm{c}, \mathrm{d}, \mathrm{f}$ and $\mathrm{g}$, even though in our work we have evidence of a pervasive greenschist facies foliation (S4) only. In that north-eastern location there are two possible interpretations: Either an anastomosing shear zone at greenschist facies comprises the main contact between the Internal and External Complexes and also between the Nery-Torché slice and the Chasten sheet. In this hypothesis, those two contacts are coeval. The second possibility is that the younger tectonic contact between Internal and External Complexes, marked by the Barmet SZ (S4), cut the greenschist facies mylonitic contact between the NeryTorché slice and the Chasten sheet $(\mathrm{S} 2+\mathrm{S} 3)$ and their lithotypes. This would imply that the Internal Complex and 2DK slice were not in contact prior to the initiation of the Barmet SZ. We cannot dismiss the first hypothesis but we favour the second one because the S2 + S3 foliation, as mapped, is cut by the $\mathrm{S} 4$ foliation which developed along the main tectonic contact (Fig. 11; Online Resource 1).

Note that the kinematics of the tectonic contact between the Internal and External Complexes are inferred from the re-orientation of the S2 by the BSZ (S4) and are consistent with those proposed in models $\mathrm{b}$ and $\mathrm{f}$. The kinematics of the $2 \mathrm{DK}$ slices are in agreement with models $\mathrm{a}, \mathrm{b}$ and $\mathrm{f}$ (Fig. 2).

Following the approach of Babist et al. (2006), we identified three fabric domains in the study area (Fig. 11b). Domain A corresponds to the main part of the Internal Complex, where the eclogite facies foliation $\mathrm{S} 2$ is the dominant fabric element. Fabric domain B corresponds to the Barmet Shear Zone, the narrow belt comprising rocks of both the Internal and External Complexes, showing the mylonitic greenschist facies foliation S4, developed during the juxtaposition of the two complexes. In the Southern part of the study area, it is difficult to delimit the boundary of this fabric domain in the External Complex, because the S4 and $\mathrm{S} 2+\mathrm{S} 3$ foliations are nearly parallel and of similar metamorphic grade. Finally, fabric domain $\mathrm{C}$ corresponds to the major part of the External Complex, where the main fabric element is the $\mathrm{S} 2+\mathrm{S} 3$ composite foliation (epidote blueschist and greenschist facies, respectively).

For the same area Babist et al. (2006) identified as well three domains (Fig. 2g). The most internal is domain 3 and is defined by moderately dipping tight folds (retrograde greenschist) that deform a previous phase 2 foliation and are related to a top to SE motion (Ometto shear Zone). Fabric domain 2, located to the west of the previous domain, is represented by a foliation steeply dipping toward NW associated with the Chiusella Shear Zone (retrograde blueschist grading to greenschist facies toward NW). Close to the contact with the Piemonte-Liguria Ocean derived units, Babist et al. (2006) identified the fabric domain 4, corresponding to the Gressoney Shear Zone of Wheeler and Butler (1993), characterized by a retrograde greenschist facies foliation with a top to E SE sense of shear.

Comparing the above fabric domains proposed in this study with those by Babist et al. (2006), there is a good match between the western part of fabric domain $\mathrm{C}$ (this study) and fabric domain 4 of Babist et al. (2006). By contrast, the eastern part of our fabric domain $\mathrm{C}$, domain $\mathrm{B}$, and the western portion of the domain A (this study) all are part of fabric domain 2 of Babist et al. (2006). In addition to this discrepancy between the two studies, we also note that the eastern part of our fabric domain A corresponds to fabric domain 3 of Babist et al. (2006) associated with the folding of previous blueschist facies fabrics occurred at greenschist facies.

\subsubsection{Thin basement sheets assembled prior}

to the pressure peak

This study, with the associated map, provides evidence that relatively thin basement sheets $(0.53 \mathrm{~km}$ in thickness) were juxtaposed during subduction, probably before either of the two Complexes reached the highest pressure, as the different sheets in each Complex share the same metamorphic imprint. In the Internal Complex, the presence of most probably monometamorphic sediment trails suggests that this part of the pre-Alpine basement was close to the surface in the Mesozoic, as proposed by Venturini et al. (1994). Pre-Alpine (Permian?) HT relics in the HP-overprinted rocks require that this basement complex must have been exhumed from lower crustal levels, likely by Triassic times, as suggested by Rebay and Spalla (2001).

In the External Complex several lower crustal slices are tectonically juxtaposed to upper continental sheets, as previous authors (Passchier et al. 1981; Vuichard 1989) had recognised.

Furthermore, this complex may contain meta-sediments of Mesozoic origin, as suggested for this area by Beltrando et al. (2014), more generally by Dal Piaz et al. (1971), and for the southern part of the Sesia Zone by Minnigh (1979) and Pognante et al. (1987).

These features suggest that the formation of small crustal sheets in both complexes could be related either to the pre-Alpine evolution of the area (i.e. sheets individuated by listric normal faults) or to subduction processes occurring before the units attained the highest metamorphic conditions recorded in each complex. 


\section{Conclusions}

In the Central Sesia Zone, two main basement complexes are in tectonic contact and represent the end result of the convergence that reorganized the previously rifted Adriatic margin.

We propose that basement rocks with a pre-Alpine upper amphibolite to granulite facies imprint (stage 1, representing late-Paleozoic lower crust) and subordinate orthogneiss make up several tectonic sheets of the Internal Complex. These are separated by thin, discontinuous trails of most likely monocyclic (Mesozoic) meta-sediments. The entire complex displays an Alpine eclogitic main foliation (S2) suggesting that the sheets were stacked during subduction, probably at eclogite facies conditions (stage 2). S2 is tightly folded during stage 3 in retrograde blueschist facies conditions.

The External Complex is composed of three main sheets of pre-Alpine upper continental crust, mostly fine-grained felsic gneisses and minor meta-sediments (paragneiss with rare calcschist, marbles and quartzites); these gneiss sheets are separated by slices of pre-Alpine lower continental crust (2DK lithotypes, retaining high-temperature relic assemblages and fabrics). The assembly of the External Complex probably predates the development of the Alpine epidote blueschist facies foliation (S2), given the similarities in the metamorphic and structural evolution within the different sheets. Stage 3 produces a S3 greenschist foliation and parallelizes the $\mathrm{S} 2$ foliation to the axial plane of $\mathrm{F} 3$ tight folds, hence a composite foliation S2 + S3 developed.

The Internal Complex is juxtaposed against the External Complex along a tectonic contact, the structural expression of which is evident in the Barmet Shear Zone. The BSZ mylonitic foliation (S4) is of greenschist grade, it truncates the eclogitic S2 of the Internal Complex at a moderate angle, and it is at a small angle or parallel to the S2 + S3 of the External Complex. Few HP relics were found inside the BSZ, suggesting HP conditions predating stage 4 . The presence of carbonate breccias with HP-fragments indicates that brittle deformation occurred at or after this HP stage.

Impure dolomite marbles and associated cornieules along the tectonic contact probably acted as weak horizons (Ulrich et al. 2002) accommodating most of the deforma-tion related to the juxtaposition of less ductile gneiss bodies. This is also reflected by the relatively narrow

$(<500 \mathrm{~m})$ deformation belt wedged between the two complexes. In the BSZ, various fragments and tectonic slices deriving from the two complexes were incorporated in a marble matrix. Assembly of the BSZ involved both brittle and ductile deformation stages.

The assembly of the entire Sesia Zone was completed during exhumation of the high-pressure belt, as reflected by the common S4 foliation and the folding phases (stages 5 and 6) that affected all of the units (Fig. 11).

In the area mapped, dykes (stage 7) are observed that are most probably related to the Periadriatic Plutons (emplaced before ca. $33 \mathrm{Ma}$, Berger et al. (2012b) and references therein). These dykes cut the eclogite facies foliation (S2, e.g. near Marine, Fig. 6i); close to the main tectonic contact, they also cut S2 overprinted by S4 (e.g. north of Albard di Bard, Fig. 61), hence their intrusion postdates S4. These dykes are locally affected by brittle fracturing (stage 8 in the Internal Complex, Fig. 61), which is possibly related to the regional rotation due to the Vanzone Fold Phase (Lanza 1977).

This detailed mapping study clarifies the tectonic situation in one of the classic areas of the Western Alps, notably along the often visited Aosta Valley (Fig. 12). Beyond this regional context, the field relations docu-mented here yield insight into the final geometry that a fragmented continental margin, with associated syn- to post-rift meta-sediments, acquired during and after sub-duction to high pressure conditions. Recently identified discrepancies in the PTthistory of several samples (Regis et al. 2014) were taken as evidence that the Internal Complex had to comprise subunits that behaved indepen-dently during part of the subduction history (as also shown by Rubatto et al. 2011). The present study confirms the

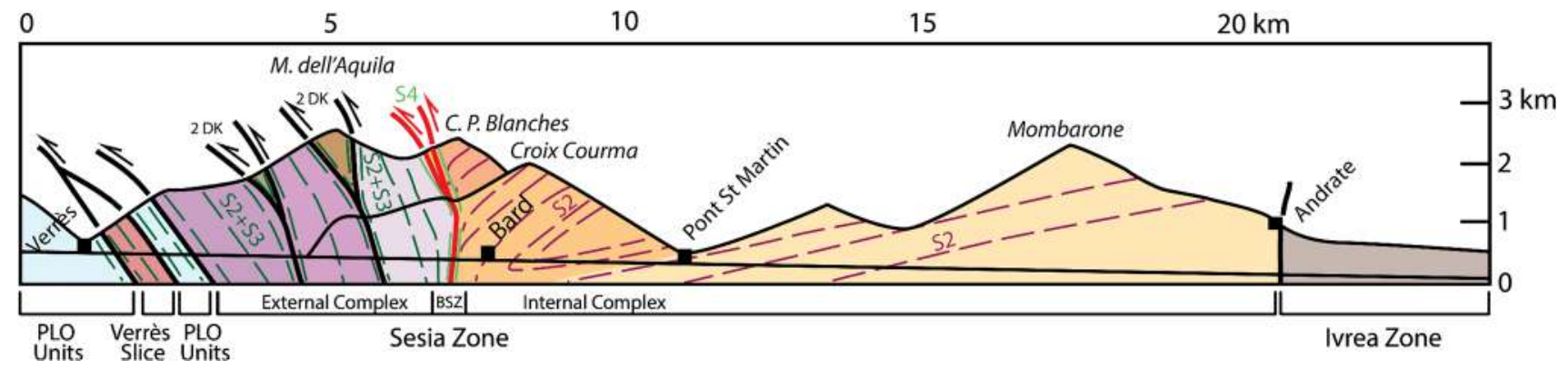

Fig. 12 Synoptic profile along Aosta Valley between Verrès and Andrate. Colour scheme as in Fig. 3, BSZ Barmet Shear Zone, PLO Piemonte Liguria Ocenic unit 
presence of several such units and documents their spatial relation, though more such sheets probably remain to be discovered. For instance, the thin trails of micaceous marble that surface on both flanks of the crest between Croix Courma and Col de la Cou might delimit another sheet, as well as the marble trail close to Château the Suzey (Online Resource 1). We recognize how difficult it is to trace tectonic contacts, even major ones such as between the Internal and External Complexes, in areas where markers (e.g. distinctive marble trails) are missing and similar lithotypes are juxtaposed (e.g. close to Bard). Yet the identification and proper delineation of such contacts is of primary importance as a basis to interpret the metamorphic and structural history of an exhumed subduction channel. Work is underway to define PT-conditions for the External Complex in order to better constrain (a) the metamorphic gap between the two complexes, and (b) the dynamic evolution of both complexes during their Alpine HP-history.

In future studies the role of thin crustal sheets involved in subduction to HP conditions should be explored, as well as the rheological behaviour of marbles along tectonic contacts.

Acknowledgments The authors dedicate this work to Marco Bel trando, mentor and friend. This work was financially supported by the Swiss National Science Foundation (Project 200020 146175). Special thanks go to P. Manzotti and M. Ballèvre for the help in the field, their many comments and helpful suggestions that substantially improved the paper. We acknowledge field assistance from M. Burn, P. Lanari, M. Robyr and M. Zucali. We thank R. Compagnoni, P. Lanari and D. Regis for fruitful discussions. H. Stünitz and C. Passchier provided original field maps and advice, and S. Hafner helped with Raman spectrometry. We thank them all, as well as C. Passchier and M. Konrad Schmolke for their insightful reviews and E. Gnos for his editorial handling.

\section{References}

Alberto, W., Carraro, F., Giardino, M. \& Tiranti, D. (2007). Genesis and evolution of 'pseudocarniole': preliminary observations from the Susa Valley (Western Alps). Geological Society, London, Special Publications, 285, 155168.

Angiboust, S., Agard, P., Raimbourg, H., Yamato, P., \& Huet, B. (2011). Subduction interface processes recorded by eclogite facies shear zones (Monviso, W. Alps). Lithos, 127, 222238.

Angiboust, S., Agard, P., Yamato, P., \& Raimbourg, H. (2012). Eclogite breccias in a subducted ophiolite: A record of interme diate depth earthquakes? Geology, 40, 707710.

Argand, E. (1911). L'exploration géologique des Alpes Pennines Centrales. Bulletin des Laboratoires de Géologie de l'Université de Lausanne, 14.

Artini, E., \& Melzi, G. (1900). Ricerche petrografiche e geologiche sulla Valsesia. Memorie del Regio Istituto Lombardo di scienze e lettere, 18, 219390.
Avigad, D. (1996). Pre collisional ductile extension in the internal western Alps (Sesia zone, Italy). Earth and Planetary Science Letters, 137, 175188.

Babist, J., Handy, M. R., Konrad Schmolke, M., \& Hammerschmidt, K. (2006). Pre collisional, multistage exhumation of subducted continental crust: The Sesia Zone, western Alps. Tectonics, 25, TC6008.

Ballèvre, M., Kiénast, J. R., \& Vuichard, J. P. (1986). La “nappe de la Dent Blanche", (Alpes occidentales): Deux unités austroalpines indépendantes. Eclogae Geologicae Helvetiae, 79, 5774.

Ballèvre, M., \& Merle, O. (1993). The Combin fault: Compressional reactivation of a Late Cretaceous Early Tertiary detachment fault in the Western Alps. Schweizerische Mineralogische und Petrographische Mitteilungen, 73, 205227.

Barnicoat, A. C., Rex, D. C., Guise, P. G., \& Cliff, R. A. (1995). The timing and nature of greenschist facies deformation and meta morphism in the upper Pennine Alps. Tectonics, 14, 279293.

Bearth, P. (1967). Die Ophiolithe der Zone von Zermatt Saas Fee. Beiträge zur Geologischen Karte der Schweiz (NF), 132 pp.

Bearth, P., Dal Piaz, G. V., Elter, G., Gosso, G., \& Martinotti, G. (1980). Il lembo di ricoprimento del Monte Emilius, Dent Blanche s.l. Atti della Reale Accademia delle scienze di Torino, 114, 226240.

Beltrando, M., Manatschal, G., Mohn, G., Dal Piaz, G. V., Vitale Brovarone, A., \& Masini, E. (2014). Recognizing remnants of magma poor rifted margins in high pressure orogenic belts: The Alpine case study. Earth Science Reviews, 131, 88115.

Berger, A., Mercolli, I., Kapferer, N., \& Fügenschuh, B. (2012a). Single and double exhumation of fault blocks in the internal Sesia Lanzo Zone and the Ivrea Verbano Zone (Biella, Italy). International Journal of Earth Sciences, 101, 18771894.

Berger, A., Thomsen, T. B., Ovtcharova, M., Kapferer, N., \& Mercolli, I. (2012b). Dating emplacement and evolution of the orogenic magmatism in the internal Western Alps: 1. The Miagliano Pluton. Swiss Journal of Geosciences, 105, 4965.

Berra, F., \& Carminati, E. (2010). Subsidence history from a backstripping analysis of the Permo Mesozoic succession of the Central Southern Alps (Northern Italy). Basin Research, 22, 952975.

Bertolani, M. (1954). Contributo allo studio petrografico della cosidetta "formazione dioritico kinzigitica"; Ricerche in Val Sabbiola (Valsesia). Rendiconti della Società Mineralogica Italiana, 10, 92207.

Bertolani, M. (1959). La formazione basica "Ivrea Verbano" e la sua posizione nel quadro geologico petrografico della bassa Val Sesia e del Biellese. Periodico di Mineralogia, 28, 151209.

Bertolani, M. (1964). Le metamorfiti dell'alta Valle Strona (Provincia di Novara). Periodico di Mineralogia, 33, 301336.

Bianconi, F. (1971). Geologia e petrografia della regione del Campolungo. PhD dissertation, Universität Zürich, 238 pp.

Biino, G., \& Compagnoni, R. (1989). The Canavese Zone between the Serra d'Ivrea and the Dora Baltea River (western Alps). Eclogae Geologicae Helvetiae, 82, 413427.

Borghi, A., Compagnoni, R., \& Sandrone, R. (1996). Composite P T paths in the Internal Penninic massifs of the Western Alps: petrological constraints to their thermomechanical evolution. Eclogae Geologicae Helvetiae, 29, 345367.

Carraro, F., Dal Piaz, G. V., \& Sacchi, R. (1970). Serie di Valpelline e II Zona Diorito Kinzigitica sono i relitti di un ricoprimento proveniente dalla zona Ivrea Verbano. Memorie della Società Geologica Italiana, 9, 197224.

Cartwright, I., \& Barnicoat, A. C. (2002). Petrology, geochronology, and tectonics of shear zones in the Zermatt Saas and Combin zones of the Western Alps. Journal of Metamorphic Geology, $20,263281$. 
Castelli, D. (1991). Eclogitic metamorphism in carbonate rocks; the example of impure marbles from the Sesia Lanzo Zone, Italian Western Alps. Journal of Metamorphic Geology, 9, 6177.

Ciarapica, G., Passeri, L., Bonetto, F. \& Dal Piaz, G. V (2016). Facies and Late Triassic fossils in the Roisan zone, Austroalpine Dent Blanche and Mt Mary Cervino nappe system, NW Alps. Swiss Journal of Geosciences, 113.

Cloos, M., \& Shreve, R. L. (1988). Subduction channel model of prism accretion, melange formation, sediment subduction, and subduction erosion at convergent plate margins: 2. Implications and discussion. Pure and Applied Geophysics, 128, 501545.

Compagnoni, R. (1977). The Sesia Lanzo Zone: high pressure low temperature metamorphism in the Austroalpine continental margin. Rendiconti della Società Italiana di Mineralogia e Petrologia, 33, 335378.

Compagnoni, R., Dal Piaz, G. V., Hunziker, J. C., Gosso, G., Lombardo, B., \& Williams, P. F. (1977). The Sesia Lanzo zone, a slice of continental crust with Alpine high pressure low temperature assemblages in the Western Italian Alps. Rendiconti della Società Italiana di Mineralogia e Petrologia, 33, 281334.

Compagnoni, R., Engi, M. \& Regis, D. (2014). Val d'Aosta section of the Sesia Zone: Multi stage HP metamorphism and assembly of a rifted continental margin. In 10th International Eclogite Conference, Syn Conference Excursion, 5 September 2013, GFT Geological Field Trips (Vol. 6 (1.2), pp. 144 ).

Dal Piaz, G. V. (1974). Le métamorphisme alpine de haute pression et basse temperature dans l'évolution structurale du bassin ophi olitique alpino apenninique. Schweizerische Mineralogische und Petrographische Mitteilungen, 54, 399424.

Dal Piaz, G. V. (1976). Il lembo di ricoprimento del Pillonet (falda della Dent Blanche nelle Alpi Occidentali). Memorie di Scienze Geologiche (Padova), 31, 160.

Dal Piaz, G. V. (1999). The Austroalpine Piedmont nappe stack and the puzzle of Alpine Tethys. Memorie di Scienze Geologiche, 51, 155176.

Dal Piaz, G. V., Bistacchi, A., \& Massironi, M. (2003). Geological outline of the Alps. Episodes, 26, 175180.

Dal Piaz, G. V., Gianotti, F., Monopoli, B., Pennacchioni, G., Tartarotti, P., \& Schiavo, A. (2010). Note illustrative della Carta Geologica d'Italia alla scala 1:50.000, Foglio 091 Châtillon. Servizio Geologico d'Italia, Foglio, 091, 5152.

Dal Piaz, G. V., Gosso, G., \& Martinotti, G. (1971). La II Zona Diorito Kinzigitica tra la Valsesia e la valle d'Ayas. Memorie della Società Geologica Italiana, 10, 257276.

Dal Piaz, G. V., Hunziker, J. C., \& Martinotti, G. (1972). La zona Sesia Lanzo e l'evoluzione tettonico metamorfica delle Alpi nordoccidentali interne. Memorie della Società Geologica Ital iana, 11, 433466.

Dal Piaz, G. V., Lombardo, B., \& Gosso, G. (1983). Metamorphic evolution of the MT. Emilius klippe, Dent Blanche nappe, Western Alps. American Journal of Science, 283, 438458.

Dal Piaz, G. V., \& Nervo, R. (1971). Il lembo di ricoprimento del Glacier Rafray (Dent Blanche s.1.). Bollettino della Società Geologica Italiana, 90, 401414.

Dal Piaz, G. V., Nervo, R. \& Polino, R. (1979b). Carta geologica del lembo del Glacier Rafray (Dent Blanche s.l.) e note illustra tive 1: 12 500. Torino: Centro Nazionale delle Richerche, Centro di studio sui problemi dell'orogeno delle Alpi Occiden tali, 2, p. 14.

Dewey, J.F., Helman, M.L., Turco, E., Hutton, D.H.W., Knott, S.D. (1989). Kinematics of the western Mediterranean. In: Coward, M.P., Dietrich, D. \& Park, R.G. (Eds.), Alpine tectonics: Geological Society of London, Special Publications, 45, 265283.
Elter, G. (1971). Schistes lustrés et ophiolites de la zone piémontaise entre Orco et Doire Baltée (Alpes Graies). Hypothèses sur l'origine des ophiolites. Géologie Alpine, 47, 147169.

Engi, M., Berger, A., \& Roselle, G. T. (2001). Role of the tectonic accretion channel in collisional orogeny. Geology, 29(12), 11431146.

Ferrando, S., Bernoulli, D., \& Compagnoni, R. (2004). The Canavese zone (internal Western Alps): a distal margin of Adria. Schweizerische Mineralogische und Petrographische Mitteilun gen, 84, 120.

Froitzheim, N., \& Manatschal, G. (1996). Kinematics of Jurassic rifting, mantle exhumation, and passive margin formation in the Austroalpine and Penninic nappes (eastern Switzerland). Geo logical Society of America Bulletin, 108, 11201133.

Fudral, S., Lu, C. Y., \& Paillet, A. (2010). Dykes and pipes of remobilized cornieules within the cornieule evaporitic complex of the Mont Jovet Area (Northwestern French Alps). Geodinam ica Acta, 23(4), 195205.

Gastaldi, B. (1871). Studi geologici sulle Alpi Occidentali. Parte I. Memorie del Regio Comitato Geologico Italiano, 1, 147.

Gastaldi, B. (1874), Studi geologici sulle Alpi Occidentali. Parte II. Memorie del Regio Comitato Geologico Italiano, 1, 147.

Gerya, T. V. \& Stöckhert, B. (2002). Exhumation rates of high pressure metamorphic rocks in subduction channels: the effect of rheology. Geophysical Research Letters 29, 8, 102101102 104.

Gosso, G. (1977). Metamorphic evolution and fold history in the eclogite micaschists of the upper Gressoney valley (Sesia Lanzo zone, Western Alps). Rendiconti della Societa' Italiana di Mineralogia e Petrologia, 33, 389407.

Gosso, G., Dal Piaz, G. V., Piovano, V., \& Polino, R. (1979). High pressure emplacement of Early Alpine nappes, postnappe defor mations and structural levels (Internal Northwestern Alps). Memorie degli Istituti di Geologia e Mineralogia dell'Università di Padova, 32, 515.

Gosso, G., Messiga, B., Rebay, G., \& Spalla, M. I. (2010). Interplay between deformation and metamorphism during eclogitization of amphibolites in the Sesia Lanzo Zone of the Western Alps. International Geology Review, 52, 11931219.

Handy, M. R., Schmid, S. M., Bousquet, R., Kissling, E., \& Bernoulli, D. (2010). Reconciling plate tectonic reconstructions of Alpine Tethys with the geological geophysical record of spreading and subduction in the Alps. Earth Science Reviews, $102(3$ 4), 121158.

Jeanbourquin, P. (1988). Nouvelles observations sur les cornieules en Suisse occidentale. Eclogae Geologicae Helvetiae, 81, 511538.

Konrad Schmolke, M., Babist, J., Handy, M. R., \& O’Brien, P. J. (2006). The physico chemical properties of a subducted slab from garnet zonation patterns (Sesia zone, Western Alps). Journal of Petrology, 47, 21232148.

Lanza, R. (1977). Paleomagnetic data from the andesitic and lamprophyric dykes of the Sesia Lanzo Zone (Western Alps). Schweizerische Mineralogische und Petrographische Mitteilun gen, 57, 281290.

Lardeaux, J. M. (1981). Evolution tectono métamorphique de la zone nord du massif de Sesia Lanzo (Alpes Occidentales): un exemple d'éclogitisation de croute continentale. $P h D$ dissertation, Université de Paris, Mémoires des Sciences de la Terre, Paris, $240 \mathrm{pp}$.

Lardeaux, J. M., Lombardo, B., Gosso, G., \& Kienast, J. R. (1982). Découverte de paragénèses à ferro omphacite dans les orthog neiss de la zone Sesia Lanzo septentrionale (Alpes Italiennes). Comptes Rendus de l'Académie des Sciences, Paris, 296, 453456. 
Lardeaux, J. M., \& Spalla, M. I. (1991). From granulites to eclogites in the Sesia zone (Italian Western Alps): a record of the opening and closure of the Piedmont ocean. Journal of Metamorphic Geology, 9, 3559.

Manzotti, P., Ballèvre, M., Zucali, M., Robyr, M., \& Engi, M. (2014a). The tectonometamorphic evolution of the Sesia Dent Blanche nappes (internal Western Alps): review and synthesis. Swiss Journal of Geosciences, 107, 309336.

Manzotti, P., Zucali, M., Ballèvre, M., Robyr, M., \& Engi, M. (2014b). Geometry and kinematics of the Roisan Cignana Shear Zone, and the evolution of the Dent Blanche Tectonic System (Western Alps). Swiss Journal of Geosciences, 107, 2347.

Minnigh, L.D., 1979. Petrological and structural investigations of the Sparone area in the Orco Valley (southern Sesia Lanzo border zone, western Italian Alps). PhD thesis, University of Leiden, p. 121.

Mohn, G., Manatschal, G., Masini, E., \& Müntener, O. (2011). Rift related inheritance in orogens: a case study from the Aus troalpine nappes in Central Alps (SE Switzerland and N Italy). International Journal of Earth Science, 100, 937961.

Nervo, R., \& Polino, R. (1976). Un lembo di cristallino Dent Blanche alla Torre Ponton (Valle d'Aosta). Bollettino della Società Geologica Italiana, 95, 647657.

Oberhänsli, R., Bousquet, R., Engi, M., Goffé, B., Gosso, G., Handy, M. R., et al. (2004). Metamorphic Structure of the Alps. Paris: CCGM (Commission of the Geological Maps of the World).

Paganelli, E., Compagnoni, R., Nervo, R. \& Tallone, S. (1995). Il lembo Austroalpino di Eaux Rousses e le sue relazioni con la Zona Ofiolitica Piemontese nell'alta Valle di Cogne, Valle d'Aosta meridionale. In Polino, R. \& Sacchi, R. (Eds), Atti convegno Alpi Appennino, Peveragno 1994, 14, pp. 335348.

Passchier, C. W., Urai, J. L., Van Loon, J., \& Williams, P. F. (1981). Structural geology of the Central Sesia Lanzo Zone. Geologie en Mijnbow, 60, 497507.

Pennacchioni, G. (1990). Evoluzione strutturale del M. Emilius (Austroalpino, Alpi Occidentali). Rendiconti della Società Geologica Italiana, 14, 97100.

Pognante, U., Talarico, F., Rastelli, N., \& Ferrati, N. (1987). High pressure metamorphism in the nappes of the Valle dell'Orco traverse (Western Alps collisional belt). Journal of Metamorphic Geology, 5, 397414.

Quick JE, Sinigoi S, Snoke AW, Kalakay TJ, Mayer A, Peressini G (2003) Geologic Map of the Southern Ivrea Verbano Zone, Northwestern Italy. Geologic Investigations Series Map I 2776 and booklet (22p). US Geological Survey, U.S. Government Printing Office.

Rebay, G., \& Spalla, M. I. (2001). Emplacement at granulite facies conditions of the Sesia Lanzo metagabbros: an early record of Permian rifting? Lithos, 58, 85104.

Regis, D., Rubatto, D., Darling, J., Cenki Tok, B., Zucali, M., \& Engi, M. (2014). Multiple metamorphic stages within an eclogite facies terrane (Sesia Zone, Western Alps) revealed by U/Th Pb petrochronology. Journal of Petrology, 55, 14291456.

Regis, D., Venturini, G., \& Engi, M. (2015). Geology of the Scalaro valley Sesia Zone (Italian Western Alps). Journal of Maps, 12, 621629.

Ridley, J. (1989). Structural and metamorphic history of a segment of the Sesia Lanzo zone, and its bearing on the kinematics of Alpine deformation in the western Alps. Geological Society Special Publications, 45, 189201.

Ring, U. (1995). Horizontal contraction or horizontal extension? Heterogeneous Late Eocene and Early Oligocene general shearing during blueschist and greenschist facies metamorphism at the Pennine Austroalpine boundary zone in the Western Alps. Geologische Rundschau, 84, 843859.

Rivalenti, G., Garuti, G., \& Rossi, A. (1975). The origin of the Ivrea Verbano basic formation (western Italian Alps); whole rock geochemistry. Bollettino della Societa Geologica ltaliana, 94, 11491186.

Rosenbaum, G., Lister, G. S., \& Duboz, C. (2002). Relative motions of Africa, Iberia and Europe during Alpine orogeny. Tectono physics, 359, 117129.

Rubatto, D., Regis, D., Hermann, J., Boston, K., Engi, M., Beltrando, M., et al. (2011). Yo Yo subduction recorded by accessory minerals in the Sesia Zone, Western Alps. Nature Geoscience, 241,3861 .

Spalla, M. I., Lardeaux, J. M., Dal Piaz, G. V., \& Gosso, G. (1991). Métamorphisme et tectonique à la marge externe de la Zone Sesia Lanzo (Alpes occidentales). Memorie di Scienze Geo logiche, 43, 361369.

Stella, A. (1894). Relazione sui rilevamento eseguito nell'anno 1893 nelle Alpi Occidentali (Valli dell'Orco e della Soana). Bollettino del Regio Comitato Geologico Italiano, 25, 343371.

Stünitz, H. (1989). Partitioning of metamorphism and deformation in the boundary region of the "Seconda Zona Diorito Kinzigitica", Sesia Zone, Western Alps. Dissertation, ETH Zürich, 244 pp.

Ulrich, S., Schulmann, K., \& Casey, M. (2002). Microstructural evolution and rheological behaviour of marbles deformed at different crustal levels. Journal of Structural Geology, 24, 979995.

Venturini, G. (1995). Geology, geochemistry and geochronology of the inner central Sesia Zone (Western Alps, Italy). Mémoires de Géologie (Lausanne), 25, 1143.

Venturini, G., Martinotti, G., Armando, G., Barbero, M., \& Hunziker, J. C. (1994). The Central Sesia Lanzo Zone (Western Italian Alps): new field observations and lithostratigraphic subdivisions. Schweizerische Mineralogische und Petrographische Mitteilun gen, 74, 115125.

Vuichard, J. P. (1986). Cinématique éo alpine et alpine en zone Sesia Lanzo (Alpes occidentales internes). Comptes Rendus de l'Académie des Sciences de Paris, 303, 13331338.

Vuichard, J. P. (1987). Conditions P T du métamorphisme anté alpin dans la "seconde zone diorito kinzigitique" (Zone Sesia Lanzo, Alpes occidentales). Schweizerische Mineralogische und Petro graphische Mitteilungen, 67, 257271.

Vuichard, J. P. (1989). La marge Austroalpine durant la collision alpine: évolution tectonométamorphique de la zone Sesia Lanzo. Mémoires et Documents du Centre Armoricain d'Etude Struc turale des Socles (Rennes), 24, 307 pp.

Warren, C. J., Beaumont, C., \& Jamieson, R. A. (2008). Formation and exhumation of ultra high pressure rocks during continental collision: role of detachment in the subduction channel. Geochemistry, Geophysics, Geosystems, 9, 4.

Wheeler, J., \& Butler, R. W. H. (1993). Evidence for extension in the western Alpine Orogen: the contact between the oceanic Piemonte and overlying continental Sesia units. Earth and Planetary Science Letters, 117, 457474.

Whitney, D. L., \& Evans, B. W. (2010). Abbreviations for names of rockforming minerals. American Mineralogist, 95, 185187.

Williams, P. F., \& Compagnoni, R. (1983). Deformation and metamorphism in the Bard area of the Sesia Lanzo Zone, Western Alps, during subduction and uplift. Journal of Meta morphic Geology, 1, 117140.

Zingg, A. (1983). The Ivrea and Strona Ceneri Zones (southern Alps, Ticino and N Italy); A review. Schweizerische Mineralogische und Petrographische Mitteilungen, 63, 361392.

Zucali, M., Spalla, M. I., \& Gosso, G. (2002). Strain partitioning and fabric evolution as a correlation tool: the example of the Eclogitic Micaschists Complex in the Sesia Lanzo Zone (Monte Mucrone Monte Mars, Western Alps, Italy). Schweizerische Mineralogische und Petrographische Mitteilungen, 82, 429454. 